\title{
Pleistocene and Holocene Landscape Development of the South Platte River Corridor, Northeastern Colorado
}

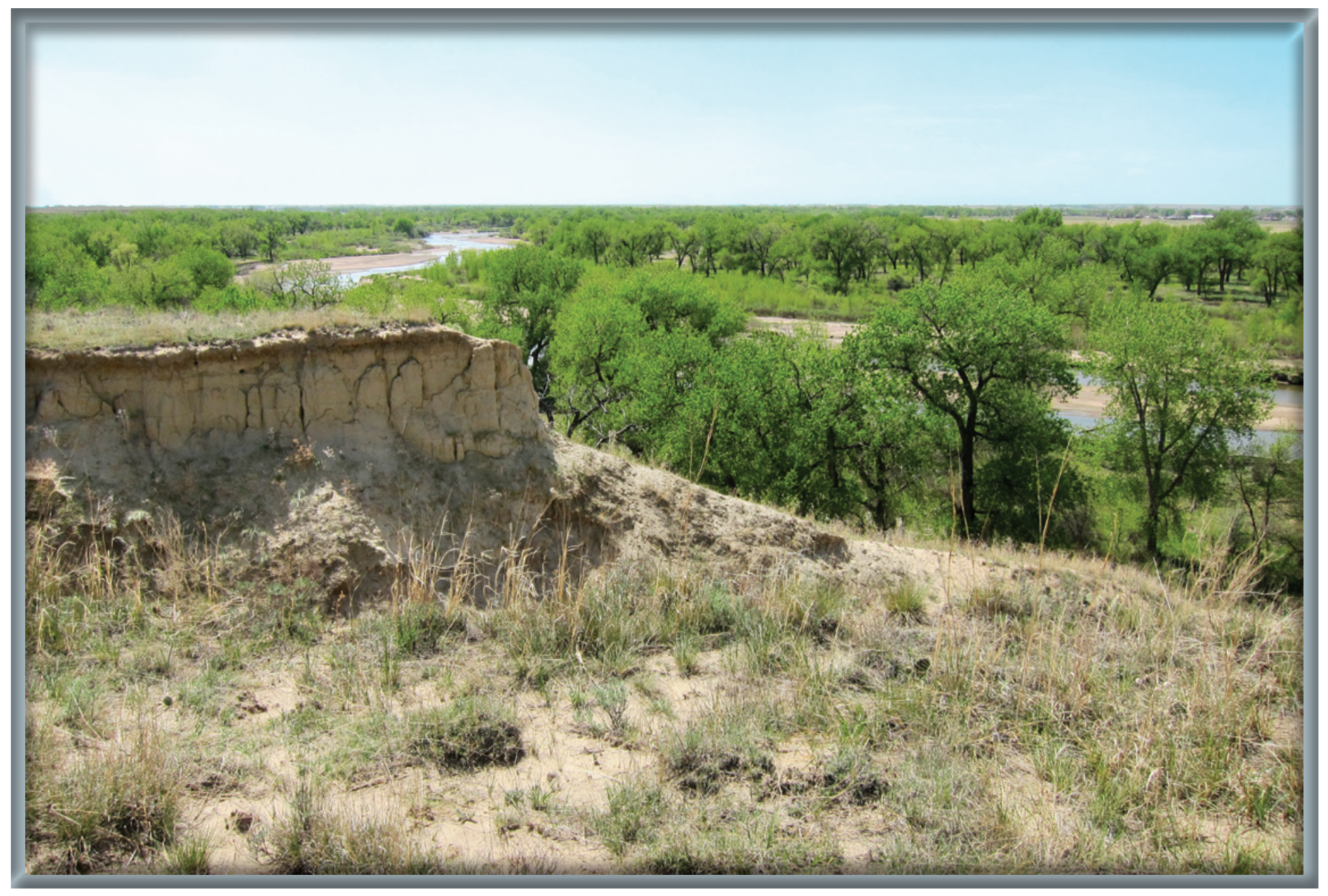

Scientific Investigations Report 2019-5020 
Cover: Photograph of the South Platte River valley near Orchard, Colorado. View is to the southwest, looking upstream along the river. The town of Orchard is visible in the background on the right side of the photograph. Photograph by M.E. Berry, April 2012. 


\section{Pleistocene and Holocene Landscape Development of the South Platte River Corridor, Northeastern Colorado}

By Margaret E. Berry, Janet L. Slate, and Emily M. Taylor

Scientific Investigations Report 2019-5020 


\title{
U.S. Department of the Interior \\ DAVID BERNHARDT, Secretary
}

\author{
U.S. Geological Survey \\ James F. Reilly II, Director
}

U.S. Geological Survey, Reston, Virginia: 2019

For more information on the USGS - the Federal source for science about the Earth, its natural and living resources, natural hazards, and the environment-visit https://www.usgs.gov or call 1-888-ASK-USGS.

For an overview of USGS information products, including maps, imagery, and publications,

visit https://store.usgs.gov.

Any use of trade, firm, or product names is for descriptive purposes only and does not imply endorsement by the U.S. Government.

Although this information product, for the most part, is in the public domain, it also may contain copyrighted materials as noted in the text. Permission to reproduce copyrighted items must be secured from the copyright owner.

\section{Suggested citation:}

Berry, M.E., Slate, J.L., and Taylor, E.M., 2019, Pleistocene and Holocene landscape development of the South Platte River corridor, northeastern Colorado: U.S. Geological Survey Scientific Investigations Report 2019-5020, 22 p., https://doi.org/10.3133/sir20195020.

ScienceBase files associated with this report can be accessed at https://doi.org/10.5066/F70N65M3

ISSN 2328-0328 (online) 


\section{Acknowledgments}

This work was part of the Greater Platte River Basins and Northern Plains Geologic Framework Studies project of the U.S. Geological Survey's National Cooperative Geologic Mapping Program. The National Association of Geoscience Teachers (NAGT)—U.S. Geological Survey (USGS) Cooperative Summer Field Training Program provided support through a student summer intern. This report is also supported by work done for the USGS geologic maps of the Orchard, Masters, Weldona, and Fort Morgan 7.5' Colorado quadrangles. We thank the many landowners who graciously granted access to their property to make this work possible. Geochronology discussed in this report was published in "Data release of OSL, 14C, and U-series age data supporting geologic mapping along the South Platte River corridor in northeastern Colorado" done with Paul R. Hanson (University of Nebraska-Lincoln) who processed and analyzed samples for optically stimulated luminescence (OSL) dating and interpreted results, and James B. Paces (USGS) who processed and analyzed samples for U-series dating and interpreted results. We also thank several other individuals who helped us in various ways. Shannon A. Mahan (USGS) provided us with a portable gamma spectrometer to measure OSL dose rates in the field. Jeffrey S. Pigati (USGS) provided guidance on radiocarbon dating methods and interpretation, identification of probable Succinea snail shells, and the submission of our radiocarbon samples for analysis. Sarah R. Survis (NAGT Intern) assisted with some of the field work. Chester A. Ruleman (USGS) provided thought-provoking discussions on landscape evolution. Jeremy C. Havens (ADC Management Services, Inc.) created the regional diagram included with this report. Jeffery R. Hartley (USGS) formatted the figures for publication. Daniel R. Muhs (USGS) and Harland L. Goldstein

(USGS) provided thorough reviews and Lisa Binder (USGS) provided editing that greatly improved this Scientific Investigations Report. 


\section{Contents}

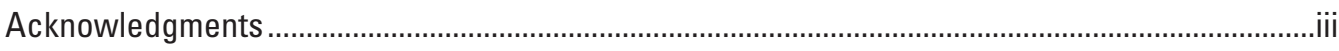

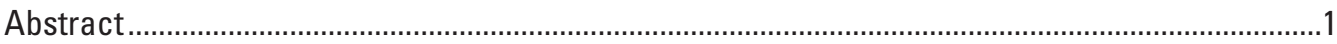

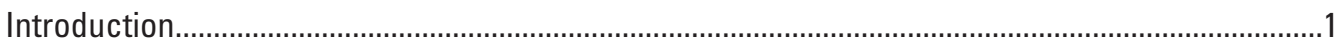

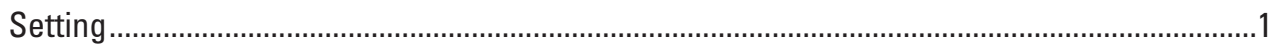

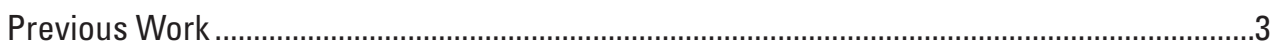

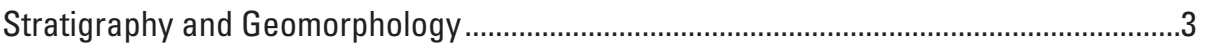

Nussbaum Alluvium ............................................................................................

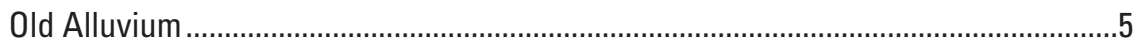

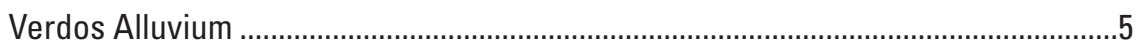

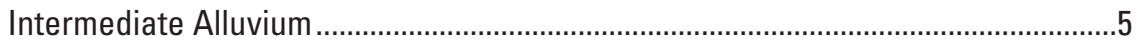

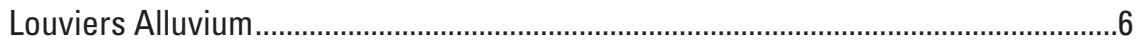

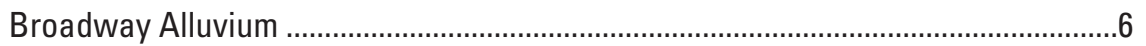

Latest Pleistocene(?) and Holocene Alluvium (Qa3) .......................................

Late Holocene Alluvium ...............................................................................................

Late Pleistocene-Holocene Transition ………………….........................................................

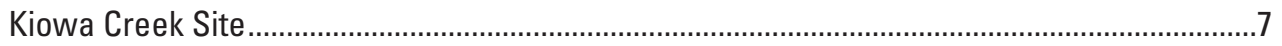

South Platte River Bluff Site ...........................................................................................

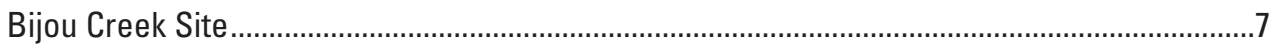

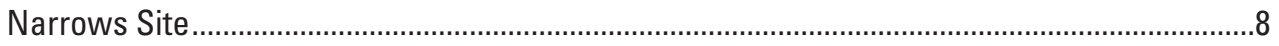

Timing of Kersey (Broadway) Terrace Formation................................................................11

Nature of Late Pleistocene-Holocene Transition ...............................................................12

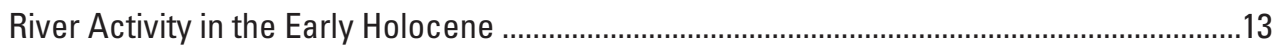

Late Holocene Terrace and Gully Formation ...............................................................................

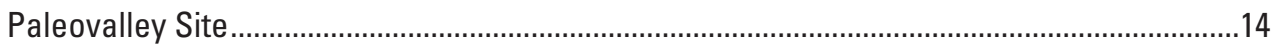

Tributary Aggradation and Incision During the Latest Holocene .............................................14

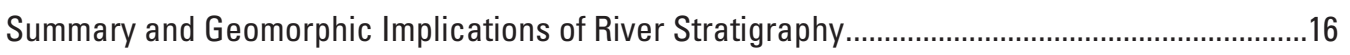

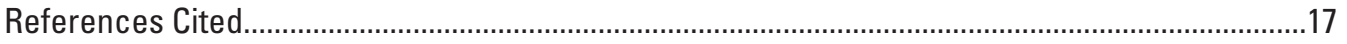




\section{Figures}

1. Location map for the study area, the South Platte River corridor, northeastern Colorado.

2. Shaded relief image of the study area, the South Platte River corridor, northeastern Colorado.

3. Simplified regional diagram illustrating the spatial relations between the South Platte, Platte, and Missouri Rivers.............................................................................

4. Kiowa Creek site in the South Platte River Corridor, Northeastern Colorado.

$A$, View of the exposure with a box marking the location of the dated section.

$B$, Close-up view of the dated section.

5. South Platte River bluff site in the South Platte River corridor, northeastern

Colorado

6. Bijou Creek site in the South Platte River corridor, northeastern Colorado ....................10

7. Narrows site in the South Platte River corridor, northeastern Colorado .........................11

8. Schematic cross section across the South Platte River, near the Narrows site in the South Platte River corridor, northeastern Colorado

9. Examples of flat-floored valleys incised by actively headward-eroding, steep-walled gullies that expose young sheetwash deposits overlying paleovalley fill in the South Platte River corridor, northeastern Colorado

10. Paleovalley site in the South Platte River corridor, northeastern Colorado.

$A$, Gully headcut exposes paleovalley fill overlain by young sheetwash deposits. $B$, Close-up view of slump block at the gully headwall. $C$, Close-up view of bones encased in young sheetwash deposits.. 


\section{Conversion Factors}

U.S. customary units to International System of Units

\begin{tabular}{|c|c|c|}
\hline Multiply & By & To obtain \\
\hline \multicolumn{3}{|c|}{ Length } \\
\hline inch (in.) & 2.54 & centimeter $(\mathrm{cm})$ \\
\hline inch (in.) & 25.4 & millimeter $(\mathrm{mm})$ \\
\hline foot $(\mathrm{ft})$ & 0.3048 & meter $(\mathrm{m})$ \\
\hline mile (mi) & 1.609 & kilometer (km) \\
\hline
\end{tabular}

International System of Units to U.S. customary units

\begin{tabular}{lcl}
\hline \multicolumn{1}{c}{ Multiply } & By & \multicolumn{1}{c}{ To obtain } \\
\hline centimeter $(\mathrm{cm})$ & Length & \\
millimeter $(\mathrm{mm})$ & 0.3937 & inch (in.) \\
meter $(\mathrm{m})$ & 0.03937 & inch (in.) \\
kilometer $(\mathrm{km})$ & 3.281 & foot (ft) \\
\hline
\end{tabular}

\section{Supplemental Information}

\section{Division of Quaternary Time Used in This Report}

\begin{tabular}{c|c|cr}
\hline \multirow{2}{*}{ Period } & Epoch & \multicolumn{2}{c}{ Age $^{1}$} \\
\hline \multirow{5}{*}{} & & late & $0-4.2 \mathrm{ka}$ \\
\multirow{3}{*}{ Quaternary } & Holocene $^{2}$ & middle & $4.2-8.2 \mathrm{ka}$ \\
\cline { 2 - 4 } & & early & $8.2-11.7 \mathrm{ka}$ \\
\cline { 2 - 4 } & \multirow{3}{*}{ Pleistocene } & late & $11.7-126 \mathrm{ka}$ \\
& & middle & $126-781 \mathrm{ka}$ \\
& & early & $781 \mathrm{ka}-2.58 \mathrm{Ma}$ \\
\hline
\end{tabular}

${ }^{1}$ Ages for time divisions are from Walker and others (2012a), Walker and others (2012b), and Cohen and others (2013). Ma, million years; ka, thousand years.

${ }^{2}$ Subdivisions of the Holocene are informal divisions advocated by Walker and others (2012b).

${ }^{3}$ Calabrian and Gelasian Ages. 


\title{
Pleistocene and Holocene Landscape Development of the South Platte River Corridor, Northeastern Colorado
}

\author{
By Margaret E. Berry, Janet L. Slate, and Emily M. Taylor
}

\section{Abstract}

This report provides a synthesis of geologic mapping and geochronologic research along the South Platte River between the town of Masters and the city of Fort Morgan, northeastern Colorado. This work was undertaken to better understand landscape development along this part of the river corridor. The focus is on times of rapid change within the fluvial system that had a marked effect on the landscape. The study area is susceptible to drought, which destabilizes vegetation and makes the landscape vulnerable to eolian activity. This is reflected in a landscape that is largely covered by eolian sand and lesser amounts of loess. Past glaciation of the river's headwaters had a major influence on river discharge and sediment supply, as have major flood events particularly on unglaciated tributaries heading on the piedmont.

In the mapping area, fluvial deposits of the South Platte River system span the Pliocene and early Pleistocene(?) deposits of Nussbaum Alluvium to present-day deposits of the active channel and floodplain. Results of the study indicate that along this stretch of the South Platte River, the early Pleistocene and first half of the middle Pleistocene were times of net incision, periodically interrupted by episodes of aggradation that resulted in deposition of alluvium that has been correlated to Rocky Flats Alluvium, Verdos Alluvium, and Slocum Alluvium. Net incision between depositional events formed a series of poorly preserved terrace deposits along the valley sides that are now largely covered by eolian deposits. Sometime after about 380 thousand years, the river cut a deep paleovalley into Upper Cretaceous Pierre Shale that was then filled with a thick sequence of inferred Louviers Alluvium (coeval with Bull Lake glaciation). Net aggradation continued during the late Pleistocene, resulting in burial of the Louviers paleovalley with a thick sequence of mainstream and sidestream Broadway Alluvium (coeval with Pinedale glaciation). Subsequent incision during the late Pleistocene-Holocene transition formed the Kersey (Broadway) terrace, whose riser forms a prominent bluff on the south side of the river valley. This episode of incision spanned a very short period and was followed by renewed aggradation that deposited the next-lower terrace alluvium (Kuner terrace alluvium). The Kuner terrace level was probably abandoned sometime around the beginning of the middle Holocene. Low terraces on the valley floor indicate that the river has been primarily cutting and backfilling laterally rather than incising during the late Holocene.

Synthesis of geologic mapping and chronologic data generated in this study indicate that the South Platte River in northeastern Colorado likely was highly sensitive to rapidly changing environmental conditions or crossed threshold conditions that triggered rapid geomorphic response during major climate changes associated with the late PleistoceneHolocene transition. Historical times have been another period marked by rapid incision, reflected by gully incision and headward erosion in tributary valleys draining the north side of the South Platte River. This historical erosion could be related at least in part to extensive construction of irrigation ditches and reservoirs in the late 1800s-early 1900s, which altered drainage paths and groundwater flow and could have amplified natural factors such as climate change or intrinsic geomorphic instabilities within the system.

\section{Introduction}

The purpose of this report is to synthesize results from geologic mapping and geochronology studies along the South Platte River between the town of Masters and the city of Fort Morgan, northeastern Colorado, to address landscape development along this part of the river corridor since the early Pleistocene (fig. 1). The focus is on the late PleistoceneHolocene transition, a time when changes in the fluvial system had a marked effect on the landscape. Historical times of apparently rapid geomorphic change are also addressed. This report is supported by ScienceBase files that can be accessed at https://doi.org/10.5066/F7QN65M3 (Berry and others, 2018a) and the U.S. Geological Survey (USGS) geologic maps of the Orchard, Masters, Weldona, and Fort Morgan 7.5' Colorado quadrangles (Berry and others, 2015a, b, 2018b, c).

\section{Setting}

This stretch of the South Platte River corridor is part of the High Plains Ecoregion, characterized by a semiarid climate with a mesic soil temperature regime, ustic and aridic soil moisture regimes, and a landscape vegetated primarily by 


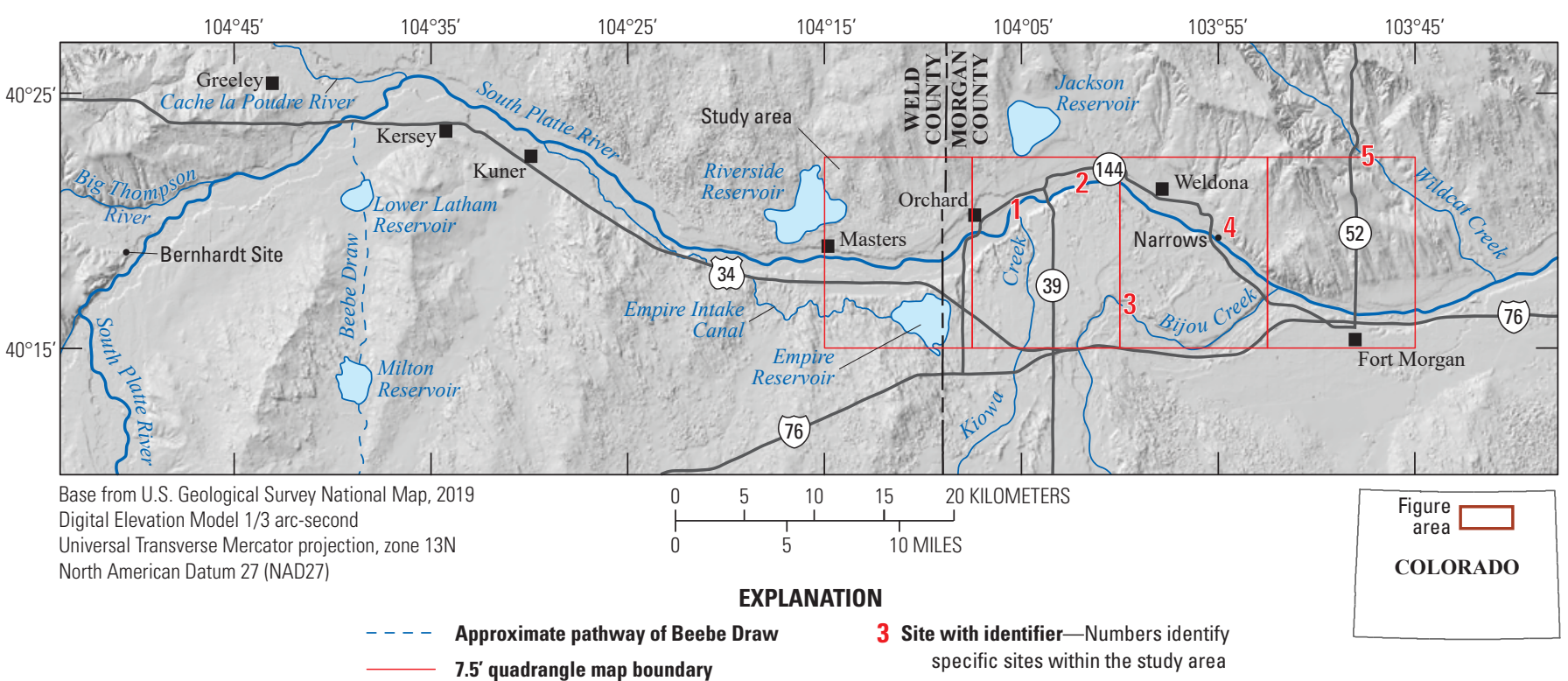

Figure 1. Location map for the study area, the South Platte River corridor, northeastern Colorado. Dashed blue line, west of the study area, shows approximate pathway of Beebe Draw. Numbers identify specific sites within the study area that are discussed in the text. 1, Kiowa Creek site; 2, South Platte River bluff site; 3, Bijou Creek site; 4, Narrows site; and 5, Paleovalley site.

short-grass and sandsage prairie; mean annual precipitation is 30-50 centimeters (cm) (Chapman and others, 2006). This type of environment is highly susceptible to drought, which destabilizes vegetation and makes the landscape vulnerable to eolian activity that can mobilize sand and silt. The multiple episodes of eolian activity during the Holocene and late Pleistocene in northeastern Colorado are well documented and indicate the environment has repeatedly undergone drought (Muhs, 1985, 2017; Madole, 1994, 1995; Forman and others, 1995; Muhs and Holliday, 1995; Muhs and others, 1996, 1999a, 1999b; Aleinikoff and others, 1999; Clarke and Rendell, 2003; Madole and others, 2005; Mahan and others, 2009; Pigati and others, 2013). Eolian sand and silt cover extensive areas of the landscape because of this activity (units Qes and Qel in the supporting maps; Berry and others, 2015a, b; 2018b, c).

This stretch of the South Platte River corridor has also been affected by past glaciation of the river's headwaters in the Colorado Rocky Mountains, which had a major influence on river discharge and sediment supply. All glaciated tributaries of the South Platte River join the river upstream from the study area, and therefore contribute discharge and sediment load to the river flowing through this stretch (Madole and others, 1998). Unglaciated tributaries heading on the piedmont also have had a large influence on sediment load of the river. Two in the study area, Kiowa and Bijou Creeks, repeatedly delivered heavy sediment loads to the South Platte River during major flood events in the late Pleistocene resulting in deposition of a large, low-gradient fan that spans their confluences (Scott, 1982; Berry and others, 2015a; 2018b) (fig. 2).

A more distant influence on the South Platte River system during the Pleistocene could have been continental glaciation, which probably had a direct effect on the Platte River into which the South Platte River flows. Distribution of glacial till (Swinehart and others, 1994) and the estimated extent of ice sheets (Barendregt and Duk-Rodkin, 2011) indicate that pre-Illinoian glacial ice could have temporarily blocked the confluence of the Platte and Missouri Rivers at the eastern edge of Nebraska, roughly 450 kilometers $(\mathrm{km})$ downstream from the confluence of the Platte and South Platte Rivers and $740 \mathrm{~km}$ downstream from the study area (fig. 3). Changes in the Platte River system due to this type of blockage would probably have been complex but could have included a temporary rise in base level that would likely have resulted in aggradation. Reopening of the river confluence during ice retreat could have lowered the base level and triggered incision. The number and timing of pre-Illinoian glaciations that could have blocked the confluence is poorly constrained, but could include multiple glaciations, with at least one possibly predating deposition of the 2.0 million-year (Ma) Huckleberry Ridge ash (Roy and others, 2004).

Finally, stream piracy and periods of minor cutting and filling unrelated to major climatic events could have had an influence on river erosion and deposition in the study area (Ritter, 1987; Kellogg and others, 2008). Along the Front Range (fig. 3) between Denver and Greeley, Colorado, the South Platte River is thought to have generally followed its present course during the early Pleistocene but shifted to flow through Beebe Draw during the middle Pleistocene (fig. 1) and shifted back to establish its present course during the late Pleistocene (Lindsey and others, 2005). Smith and others (1964) attribute the abandonment of the river's course through Beebe Draw to stream piracy. 


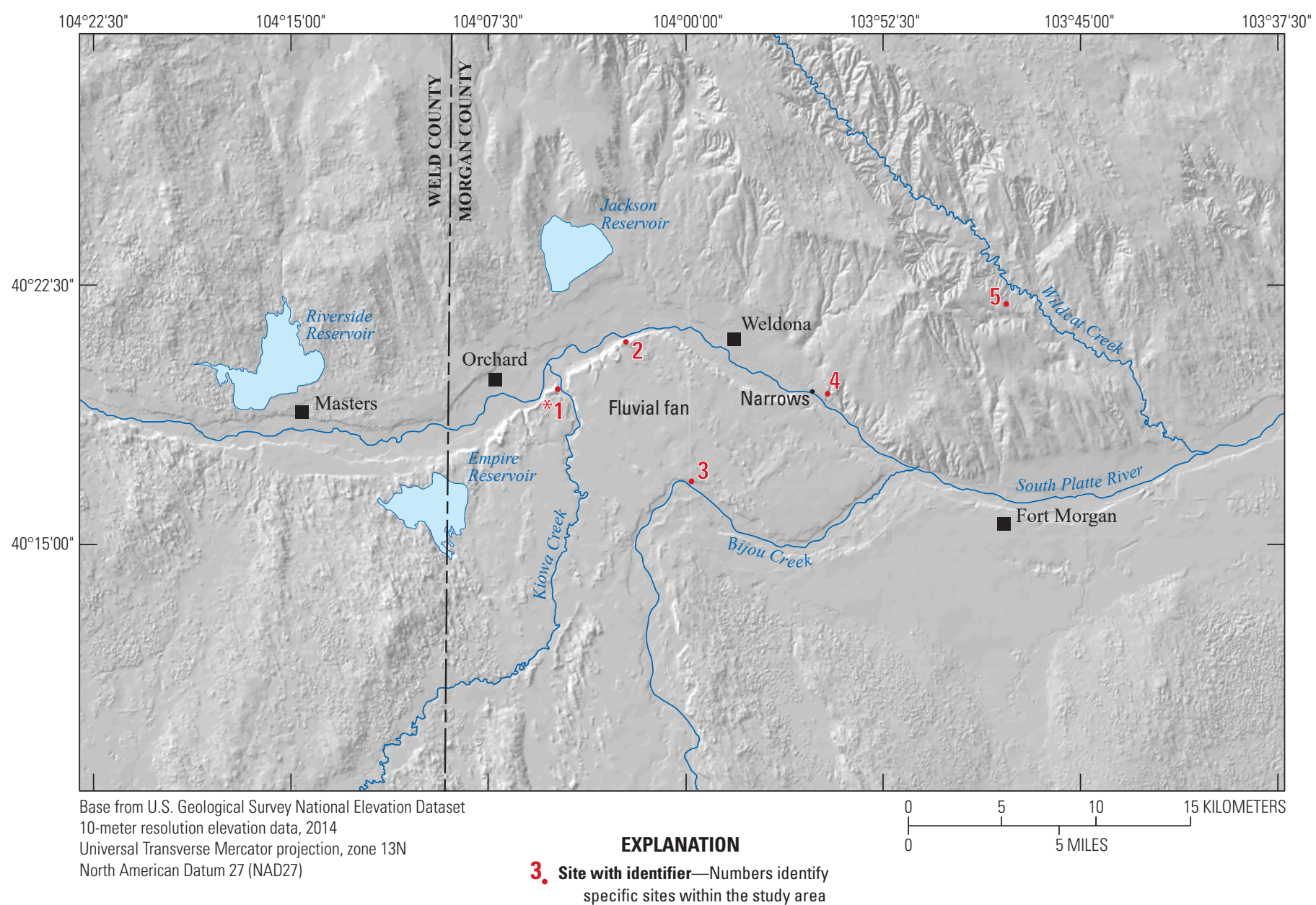

Figure 2. Shaded relief image of the study area, the South Platte River corridor, northeastern Colorado. Low-gradient fan visible in center of image is mostly made up of late Pleistocene sheetflood deposits from Kiowa and Bijou Creeks. Much of the area visible in the image is covered by variable thicknesses of Holocene and late Pleistocene eolian sand, and locally loess. Numbers identify specific sites within the study area that are discussed in the text: 1, Kiowa Creek site; 2, South Platte River bluff site; 3, Bijou Creek site; 4, Narrows site; and 5, Paleovalley site. Asterisk marks site TK-R from Berry and others (2015a), located along the South Platte River bluff about 0.8 kilometers upstream from the Kiowa Creek site.

\section{Previous Work}

This report is an outgrowth of geologic mapping and geochronological studies carried out by Berry and others (2015a, b; 2018a, b, c) along the South Platte River corridor between Masters and Fort Morgan, Colo., which built upon previous work by Gardner (1967) and Scott $(1978,1982)$. Much of the stratigraphic nomenclature originated from Scott's (1960, 1963) work along the Front Range, which he later extended into northeastern Colorado (Scott, 1978, 1982), but the nomenclature also includes stratigraphic names that Scott adopted or modified from Gilbert (1897) and Hunt (1954). Terrace names referenced in this report originated from Bryan and Ray (1940) and Hunt (1954) and have been previously applied to terraces within the present study area by Gardner (1967), McFaul and others (1994), and Muhs and others (1996).

All radiocarbon ages referenced in this report were calibrated to calendar years ( 0 yr before present [B.P.] $=1950$ anno Domini [A.D.]) by Berry and others (2015a, b; 2018a, b, c) using the IntCal13 dataset and CALIB 7.0 (Stuiver and Reimer, 1993; Reimer and others, 2013) for better comparison to ages generated by other dating methods. Calibrated radiocarbon ages are expressed as "cal ka B.P.," which stands for calibrated thousand years before present, and uncertainties are given at the 95 percent (2 sigma $[\sigma]$ ) confidence level. Calibrated ages are reported as the midpoint of the calibrated range. In cases where calibration produced more than one age range with a probability of 5 percent or more, ages are based on the mean of the ranges weighted by their probabilities and are given without uncertainties.

\section{Stratigraphy and Geomorphology}

This study focused on fluvial deposits of the South Platte River system that span the Pliocene and early Pleistocene(?) deposits of Nussbaum Alluvium to present-day deposits of 


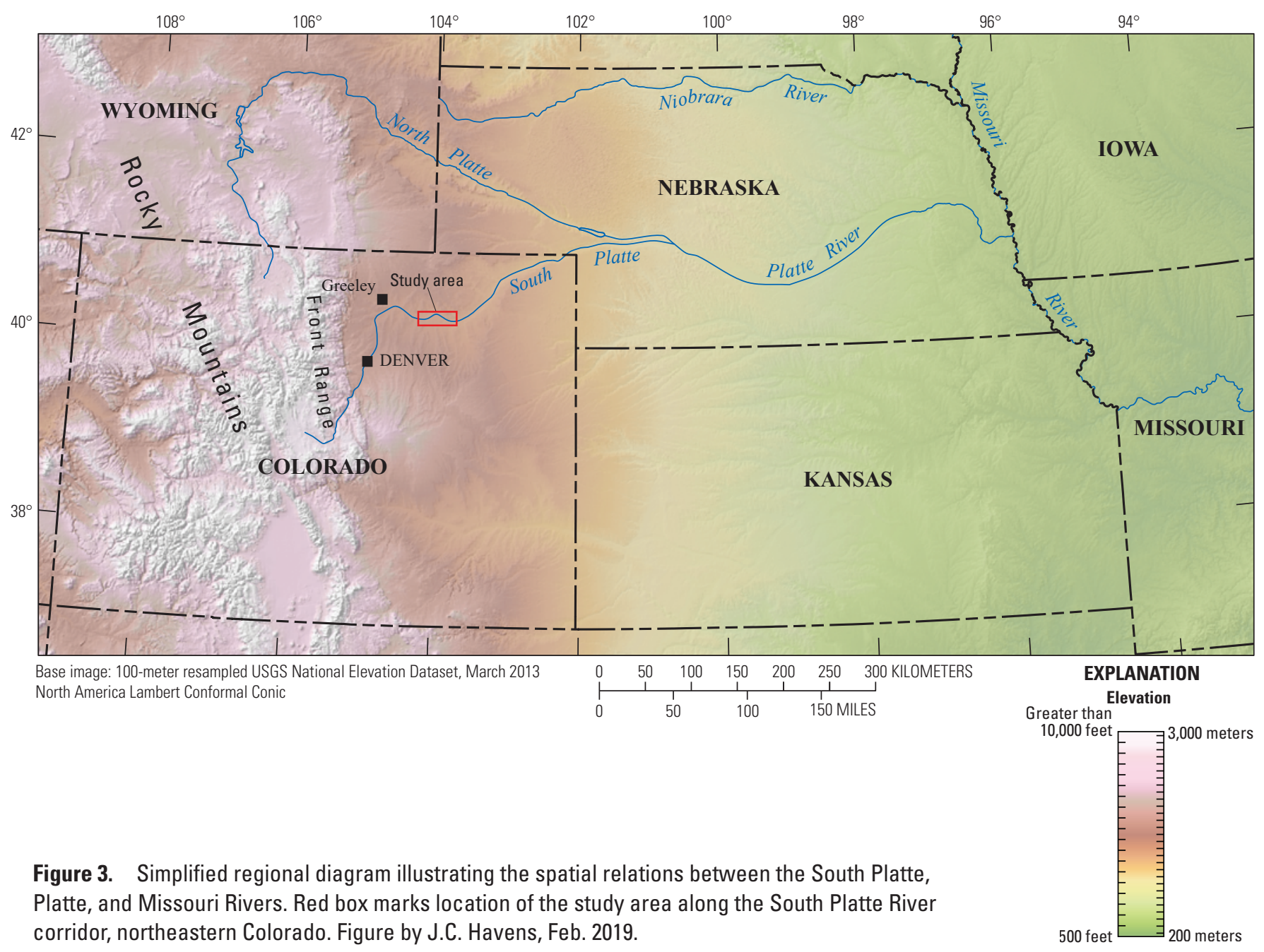

Platte, and Missouri Rivers. Red box marks location of the study area along the South Platte River corridor, northeastern Colorado. Figure by J.C. Havens, Feb. 2019.

the active channel and floodplain (Gardner, 1967; Scott, 1978, 1982; Berry and others, 2015a, b; 2018b, c). Primary and reworked deposits of Holocene and late Pleistocene eolian sand, and locally loess, cover much of the landscape, but stream and gully cuts, gravel pits, canal ditches, and road cuts provide local exposure of the fluvial deposits. Lithologic data from test holes, water wells, and oil and gas drill holes (Bjorklund and Brown, 1957; Colorado Division of Water Resources, 2013) provide information about buried deposits.

Descriptions of the fluvial deposits included here are from the USGS geologic maps of the Orchard, Masters, Weldona, and Fort Morgan 7.5' Colorado quadrangles (Berry and others (2015a, b; 2018b, c), and the supporting data release (Berry and others, 2018a).

\section{Nussbaum Alluvium}

The Nussbaum Alluvium (QNn) of Gardner (1967) and Scott $(1978,1982)$, exposed locally in gravel pits and in the headwalls of box canyons north of the river, is preserved in remnant deposits overlying the Upper Cretaceous Pierre
Shale (Kp) roughly $122-137$ meters $(\mathrm{m})$ above the active floodplain (Berry and others, 2018c). Estimated thickness of preserved deposits is 7-12 $\mathrm{m}$, although the original thickness could have been as much as $21 \mathrm{~m}$ based on a section Scott (1982) measured downstream from Fort Morgan. Scott (1982) considered the Nussbaum Alluvium to be about $3 \mathrm{Ma}$ (Pliocene) based on its geomorphic position, fossil assemblages, and inferred ages of Stegomastodon fossils collected from the alluvium at sites northeast of Fort Morgan (Scott, 1982). Scott used the fossil evidence and geomorphic position to correlate Nussbaum Alluvium with the Broadwater Formation of western Nebraska. He also used fossil evidence to demonstrate equivalence between the Broadwater Formation and the Blanco Formation of Texas (Scott, 1982; Madole, 1991). The latter has an age of late Pliocene and early Pleistocene based on the ages of Blanco and Guaje ash beds associated with it (see Bell and others, 2004). Scott's correlations, combined with the age range for Stegomastodon (Pliocene and early Pleistocene, Bell and others, 2004), leave open the possibility that the age range of Nussbaum Alluvium likewise extends into the early Pleistocene. 


\section{Old Alluvium}

Deposits of old alluvium (Qao) that could correlate to Rocky Flats Alluvium (Gardner, 1967; Scott, 1978, 1982) are mostly buried, but are exposed locally in gravel pits or inferred from drill hole data (Bjorklund and Brown, 1957; Colorado Division of Water Resources, 2013). The Qao deposits, which overlie Pierre Shale, form inferred terrace remnants roughly 60-70 $\mathrm{m}$ above the active floodplain (Berry and others, 2015b, 2018c). Thickness of the deposits is poorly constrained but is probably at least $9 \mathrm{~m}$, and locally could be more than 15-20 m. Along the Front Range, the oldest deposits of Rocky Flats Alluvium are thought to have an estimated age of at least 1.6-1.4 Ma (Birkeland and others, 1996) or about 2 Ma (Birkeland and others, 2003) based on soil development and paleomagnetic data. Similarly, oldest ages of about 1.5 Ma (Dethier and others, 2001) to about $2 \mathrm{Ma}$ (Riihimaki and others, 2006) are indicated by cosmogenic radionuclide (CRN) data. Results from CRN studies, however, indicate a complicated alluvial history for associated terrace surfaces (Riihimaki and others, 2006; Dühnforth and others, 2012; Foster and others, 2015, 2016), and near the Front Range, parts of the Rocky Flats surface may be as young as 400 thousand years (ka) (Riihimaki and others, 2006). In northeastern Colorado, a fossil tooth (Stegomastodon elegans) in old alluvium correlated to Rocky Flats Alluvium by Scott (1982) was collected at a site downstream from Fort Morgan (NW $1 \frac{1}{4} \mathrm{SW}^{1} \frac{1}{4}$, sec. 7, T. 5 N., R. 55 W.) and used by Scott to assign an early Pleistocene age to the deposit.

\section{Verdos Alluvium}

Verdos Alluvium (Qv) is locally exposed along canals and in gravel pits, in deposits estimated to be about 6-10 m thick (Gardner,1967; Scott, 1978, 1982; Berry and others, 2018b, c). The alluvium is mostly preserved in terrace remnants overlying Pierre Shale, roughly 49-55 m above the South Platte River floodplain, although a few poorly preserved remnants 44-45 m above the floodplain may indicate a second, lower level of Verdos Alluvium, as Scott (1972) and Kellogg and others (2008) report for the west Denver metropolitan area. The age of the Verdos Alluvium is constrained by its association with the Lava Creek B ash (Scott, 1960; Madole, 1991; Kellogg and others, 2008; and references therein), which was erupted from the Yellowstone Plateau volcanic field about 631 ka (Matthews and others, 2015). Although no deposits of Lava Creek B ash have been identified within the study area, ash has been reported in outcrops of Verdos Alluvium at several sites along the South Platte River corridor to the northeast (see Scott, 1978, 1982; Izett and Wilcox, 1982).

\section{Intermediate Alluvium}

Alluvial deposits of intermediate age (Qai) that could correlate to Slocum Alluvium (Gardner,1967; Scott, 1978, 1982; Berry and others, 2015b, 2018b, c) are generally poorly exposed and poorly preserved, but are identified in the Masters area roughly $24 \mathrm{~m}$ above the active floodplain. In this area, the alluvial deposits are covered entirely by eolian sand, but are exposed locally along the Empire Intake canal (fig. 1) and in a gravel pit near Qai exposures along the canal (Berry and others, 2015b). The alluvial deposits, which overlie Pierre Shale, are also identified near Weldona, Colo., roughly 34-40 $\mathrm{m}$ above the floodplain, and at two levels downstream from the Narrows, one roughly 32-40 m (Qai2) and the other 21-25 m (Qai1) above the active floodplain (Berry and others, 2018 b, c). Preserved thickness of the alluvial deposits is highly variable, but locally could be as much as $12-18 \mathrm{~m}$.

Qai alluvium exposed in a canal ditch near Empire Reservoir has been dated using the uranium-series method (Paces, 2015; Berry and others, 2018a). The analyses were done on innermost pedogenic calcium carbonate rinds, subsampled from multiple clasts collected at a depth of about 100-120 centimeters $(\mathrm{cm})$. The analyses produced oldest ${ }^{230} \mathrm{Th} / \mathrm{U}$ ages that cluster primarily in two groups, one with an error-weighted-mean age of $334 \pm 9 \mathrm{ka}$ and the other with an error-weighted-mean age of $382 \pm 16 \mathrm{ka}$ (see sample EIC-Wp95 in Paces, 2015). The age difference between clusters probably reflects differences in timing of calcium carbonate accumulation within the soil. Because the method dates a product of soil development, the oldest ${ }^{230} \mathrm{Th} / \mathrm{U}$ ages are considered to be a minimum age estimate for the deposit in which the soil formed. These results indicate deposition of the alluvial clasts occurred sometime prior to about $334 \mathrm{ka}$, with about $382 \mathrm{ka}$ probably being closest temporally to the minimum age of the deposit. These ages fall within a range proposed for "older deposits" of Slocum Alluvium by Kellogg and others (2008), who recognized two levels of Slocum Alluvium locally along the Front Range and proposed an age range of 320-390 ka for the higher (older) deposits. The estimated age ranges of Kellogg and others (2008) assume that the timing of alluvium deposition along the Front Range tentatively correlates with marine oxygen isotope stages (stages 9-11 for the "older deposits" of Slocum Alluvium), and that rates of river incision since deposition of the Lava Creek B ash were nonlinear. Only a few actual ages have been obtained for deposits considered to be Slocum Alluvium (for example, see Szabo, 1980). More data are needed to substantiate the age of Slocum Alluvium and to firmly establish its relation to intermediate alluvial deposits along this part of the South Platte River corridor. The dated Qai alluvium near Empire Reservoir is inferred to be part of a terrace remnant roughly $24 \mathrm{~m}$ above the modern floodplain, but the terrace is buried and cannot be directly traced downstream to where two levels of terraces are recognized (Berry and others, 2018b, c). A height of $24 \mathrm{~m}$ could suggest correspondence with the lower (younger) Qai terrace deposits (Qai1) in the Weldona-Fort Morgan area. It should be noted, however, that the gradient of the ancestral South Platte River between Masters and Fort Morgan appears to have been more gentle than that of the modern river at times in the past, based on height of the latest Pleistocene(?) and Holocene terrace (Qa3), which is clearly traceable downstream (Berry and others 2018b). Therefore, it is possible that the dated Qai alluvium corresponds to the higher (older) terrace deposits (Qai2) instead. 


\section{Louviers Alluvium}

Deposits interpreted as Louviers Alluvium (Qlv) are not exposed in the study area but are inferred from lithologic data from test holes and water wells (Bjorklund and Brown, 1957; Gardner, 1967; Scott, 1978, 1982; Colorado Division of Water Resources, 2013; Berry and others, 2015a, b). Evidence supporting their presence under younger deposits of late Pleistocene Broadway Alluvium includes maximum total thickness of alluvium overlying Pierre Shale, which locally is over $70 \mathrm{~m}$ where side-stream deposits from Kiowa and Bijou Creeks contribute to the total thickness, and up to $50 \mathrm{~m}$ where they do not. In addition, the maximum total width of the buried alluvial paleovalley, more than $13 \mathrm{~km}$ under the Orchard area (Berry and others, 2015a), is anomalously wide for a single paleovalley. These factors, combined with evidence in the drill hole data of deep paleochannels south of the modern South Platte River, indicate that the river was probably south of its present position along much of the reach between Masters and Fort Morgan at the time the Louviers Alluvium was deposited, but shifted back to the north during the late Pleistocene (Bjorklund and Brown, 1957; Gardner, 1967; Scott, 1978, 1982; Colorado Division of Water Resources, 2013). The Louviers level was most likely abandoned by incision before a return to net aggradation of the river system resulted in burial of the Louviers Alluvium by late Pleistocene Broadway Alluvium.

The Louviers Alluvium is considered coeval with the Bull Lake glaciation (Scott, 1975; Madole, 1991; see discussion of U-series ages for Louviers Alluvium in Szabo, 1980). The Bull Lake glaciation is thought to have spanned a period from about $190 \mathrm{ka}$ to less than or equal to $(\leq) 130 \mathrm{ka}$ (see discussions in Madole, 1991; Schildgen and others, 2002; Pierce, 2003; Sharp and others, 2003; Benson and others, 2004; Kellogg and others, 2008; Licciardi and Pierce, 2008; Schweinsberg and others, 2016). Fluvial sediment load may have been greatest during and shortly after deglaciation (Church and Ryder, 1972; Madole, 1991; Schildgen and others, 2002; Lindsey and others, 2005). Therefore, some of the youngest alluvium may post-date the Bull Lake glaciation by a few thousand years (Kellogg and others, 2008).

\section{Broadway Alluvium}

Mainstream (Qba) and sidestream (Qbs) deposits of Broadway Alluvium are the predominant fluvial deposits in the study area. Mainstream deposits form a terrace, best preserved near Masters, that is about $12-15 \mathrm{~m}$ above the active floodplain of the South Platte River. The terrace can be traced upstream and thereby correlated to the Kersey terrace of Bryan and Ray (1940) near Kersey, Colorado (fig. 1). This relation has been noted by numerous workers (Gardner, 1967; Holliday, 1987; McFaul and others, 1994; Muhs and others, 1996). The Kersey terrace of Bryan and Ray (1940) is considered the downstream equivalent of the Broadway terrace of Hunt (1954) in the Denver area (Scott, 1963, 1978, 1982; Gardner, 1967; Colton, 1978; Holliday, 1987; Madole, 1991; McFaul and others, 1994; Haynes and others, 1998).
Sidestream alluvium in the study area consists mainly of sheetflood deposits interpreted to have been deposited primarily by large-magnitude floods along Bijou and Kiowa Creeks (Gardner, 1967; Scott, 1978, 1982; Berry and others, 2015a, $2018 \mathrm{~b}$ ). The deposits, which overlie and are interpreted to interfinger with mainstream alluvium, form a low-gradient fan that slopes gently toward the South Platte River, and reaches a maximum height of approximately $27 \mathrm{~m}$ above the active floodplain near the Bijou Creek confluence. The sidestream alluvium is more cohesive than the mainstream alluvium and forms a prominent bluff along the south side of the river. Based on bluff exposures and drill hole data from Bjorklund and Brown (1957) and the Colorado Division of Water Resources (2013), thicknesses of Broadway Alluvium could range from about 6-24 $\mathrm{m}$ for the sidestream deposits, and $12-30 \mathrm{~m}$ for the mainstream deposits.

Broadway Alluvium is considered coeval with the Pinedale glaciation (Bryan and Ray, 1940; Hunt, 1954; Scott, 1960, 1975; Madole, 1991), which spanned a period from greater than (>)31 ka to about 15-13 ka (Nelson and others, 1979; Madole, 1986; Schildgen and others, 2002; Benson and others, 2004, 2007; Licciardi and Pierce, 2008; Madole and others, 2010; Young and others, 2011; Schweinsberg and others, 2016). Similar to Louviers Alluvium, fluvial sediment load may have been greatest during and shortly after deglaciation (Church and Ryder, 1972; Madole, 1991; Schildgen and others, 2002; Lindsey and others, 2005), a process that started either about $17 \mathrm{ka}$ (Licciardi and others, 2004; Benson and others, 2005; Schaefer and others, 2006) or about 16-15 ka (Young and others, 2011), and for the most part completed between about 15 and 13 ka (Benson and others, 2007; Young and others, 2011; and references therein).

\section{Latest Pleistocene(?) and Holocene Alluvium (Qa3)}

Latest Pleistocene(?) and Holocene alluvium (Qa3) forms a terrace along much of the river corridor within the study area. The terrace alluvium, estimated to be $2-6 \mathrm{~m}$ thick, is interbedded with sheetwash deposits and colluvium, notably on the north side of the South Platte River valley, where the valley wall is cut into Pierre Shale. The terrace surface, which is traceable downstream, is about $3-6 \mathrm{~m}$ above the active floodplain in the Masters and Orchard areas, but increases in height to about 6-11 $\mathrm{m}$ near the Narrows and about 8-12 m near Fort Morgan (Berry and others, 2015a, b; 2018b, c). Gardner (1967), McFaul and others (1994), and Haynes and others (1998) all considered the terrace to be equivalent to the Kuner terrace of Bryan and Ray (1940), which is about $3.5-6 \mathrm{~m}$ above the active floodplain at its type locality near Kuner, Colorado (fig. 1). However, poor preservation of the terrace between Kuner and the study area preclude a direct correlation (Holliday, 1987). The Kuner terrace, in turn, could be the downstream equivalent of the Piney Creek terrace in the Denver area (see Scott, 1963, p. 47), which is about 4.5-6 m above modern stream level. The Qa3 terrace alluvium has been called Piney Creek Alluvium by previous workers (Gardner, 1967; Scott, 1978). 
However, radiocarbon ages for Piney Creek Alluvium at its type locality are late Holocene (Hunt, 1954; Scott, 1963; Madole and others, 2005), whereas ages for Qa3 alluvium in the study area, as well as ages for the Kuner terrace alluvium (Haynes and others, 1998), are latest Pleistocene(?) and Holocene (Berry and others, 2015a, b; 2018b, c). The latest Pleistocene(?) and Holocene ages are discussed in more detail in the "Narrows Site" and the "Nature of Late Pleistocene-Holocene Transition" sections of this report.

\section{Late Holocene Alluvium}

The valley floor of the South Platte River is made up of active channel and floodplain deposits (Qaa), and young alluvium forming two low terraces, generally $1.5 \mathrm{~m}$ (Qa1) and $3 \mathrm{~m}$ (Qa2) above the active floodplain. The South Platte River valley has been highly engineered in places, with numerous levees and river control structures that have altered how the floodplain and terraces are inundated by floodwaters. For example, parts of the lowest terrace surface near Fort Morgan were within the active floodplain as recently as the 1960s (Gardner, 1967), but shifts in river course and the addition of artificial levees now protect these areas from frequent flooding. The low terrace, floodplain, and channel alluvium correlate at least in part to post-Piney Creek alluvium of Scott (1963).

Deposits of the late Holocene alluvium are relatively thin, each estimated to be about 3-6 m thick. Near Weldona and Fort Morgan, where the modern South Platte River valley is either at, or near, the northern edge of its bedrock valley, Holocene alluvium overlies Pierre Shale. Elsewhere, these deposits form a veneer over thicker sections of Pleistocene alluvium (Berry and others, 2015a, b; 2018b, c).

\section{Late Pleistocene-Holocene Transition}

Optically stimulated luminescence (OSL) and radiocarbon $\left({ }^{14} \mathrm{C}\right)$ age estimates for terrace alluvium at several sites within the study area provide information about the timing of river aggradation and incision associated with terrace formation around the time of the late Pleistocene-Holocene transition (fig. 2; Berry and others, 2015a, b; 2018a, b, c). Site names used here correspond to geochronology site names used in Berry and others (2015a, b; 2018a, b, c) as follows: Kiowa Creek site, KC; South Platte River bluff site, H-R; Bijou Creek site, BC; Narrows site, AK; and the Paleovalley site, TIP.

\section{Kiowa Creek Site}

The Kiowa Creek site is located at a bluff exposure on Kiowa Creek near its confluence with the South Platte River on the Orchard 7.5' quadrangle (figs. 2 and 4; Berry and others, 2015a). At the site, about a half meter of Holocene eolian sand overlies sheetflood deposits of sidestream Broadway Alluvium. Unlike mainstream Broadway Alluvium, which contains a large component of crystalline rock types derived from the mountains, the sidestream deposits are mostly derived from Upper Cretaceous and Tertiary sedimentary rocks exposed in Kiowa Creek and adjacent Bijou Creek drainages, which head on the Colorado Piedmont (Braddock and Cole, 1978; Sharps, 1980; Bryant and others, 1981). The sidestream deposits tend to form near-vertical faces in the upper part of bluff exposures. In contrast, mainstream deposits crop out poorly due to a loose dry consistence. At the Kiowa Creek site, mainstream deposits of Broadway Alluvium underlie the sidestream deposits but are buried by colluvium. A sequence of three OSL age estimates were obtained for sidestream Broadway Alluvium: $12.0 \pm 1.1 \mathrm{ka}(\mathrm{UNL}-3462)$ at a depth of about $1.7 \mathrm{~m}$; $16.8 \pm 1.7 \mathrm{ka}$ (UNL-3466) at a depth of about $2.6 \mathrm{~m}$; and $15.2 \pm 1.5 \mathrm{ka}$ (UNL-3463) at a depth of about $3.6 \mathrm{~m}$ (fig. 4; Berry and others, 2015a, 2018a). Although the lower two ages are stratigraphically reversed, they are within analytical uncertainty of one another, indicating that the dated sediment could have been deposited during closely spaced flood events. Other factors contributing to a relatively older age for the middle sample could include incomplete bleaching of fluvial sediments due to rapid deposition during floods or deposition at night. The age estimates indicate a late Pleistocene age for sidestream Broadway Alluvium. The ages also indicate that aggradation of the sidestream alluvium could still have been in progress about $12 \mathrm{ka}$ but allow for the possibility that the terrace surface was abandoned shortly thereafter.

\section{South Platte River Bluff Site}

The South Platte River bluff site, also on the Orchard $7.5^{\prime}$ quadrangle, is located about $5 \mathrm{~km}$ downstream from the Kiowa Creek confluence, at a well-exposed section of sidestream Broadway Alluvium (figs. 2, 5; Berry and others, 2015a). As at the Kiowa Creek site, about a half a meter of eolian sand overlies the alluvial section at the site. Probable Succinea snail shells, which have been shown to provide reliable ${ }^{14} \mathrm{C}$ dates (Pigati and others, 2010), were present in a $15-\mathrm{cm}$-thick silt bed at a depth of about $3.7 \mathrm{~m}$ in the section (fig. 5). Four small shells collected from the silt bed were combined for dating and had an estimated age of $14.53 \pm 0.56$ cal ka B.P. $\left(12.36 \pm 0.15{ }^{14} \mathrm{C}\right.$ ka B.P., Aeon-1064; Berry and others, 2015a, 2018a). This age estimate is similar to the OSL age obtained for sidestream Broadway Alluvium at a similar depth in the section at the Kiowa Creek site (UNL-3463, Berry and others, 2015a, 2018a), indicating good agreement between dating methods.

\section{Bijou Creek Site}

The Bijou Creek site is located on Bijou Creek about $15 \mathrm{~km}$ upstream from its confluence with the South Platte River, and roughly $10 \mathrm{~km}$ southeast of the Kiowa Creek site on the Weldona 7.5' quadrangle (fig. 2; Berry and others, 2018b). The exposure is at the edge of a terrace made up of 


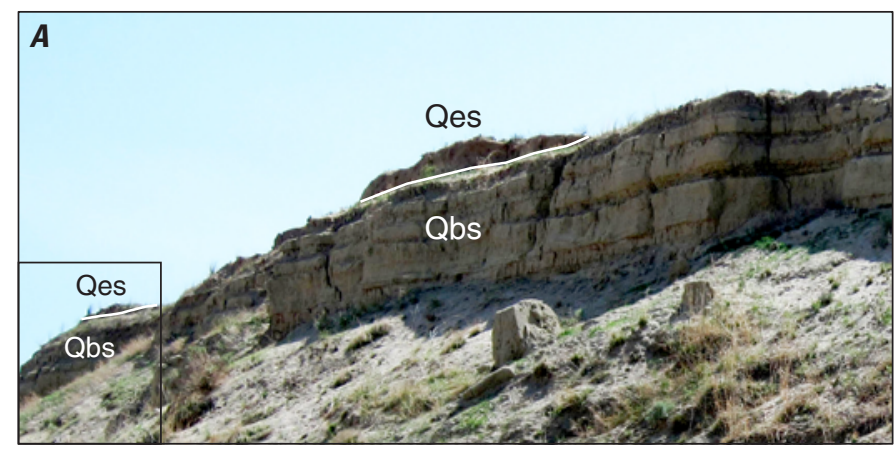

Figure 4. Kiowa Creek site in the South Platte River Corridor, northeastern Colorado. Qes, eolian sand; Qbs, sidestream deposits of Broadway Alluvium. Mainstream deposits of Broadway Alluvium underlie Qbs but are buried by colluvium at this site. $A$, View of the exposure with a box marking the location of the dated section. $B$, Close-up view of the dated section. Here, about 0.5 meter $(\mathrm{m})$ of Qes (not visible in photograph) overlies several meters of $Q b s$. A sequence of three optically stimulated luminescence age estimates were obtained for Qbs: 12.0 1.1 thousand years (ka) (UNL-3462) at a depth of about $1.7 \mathrm{~m}$ (sample site just to the right of photograph); $16.8 \pm 1.7 \mathrm{ka}(\mathrm{UNL}-3466)$ at a depth of about $2.6 \mathrm{~m}$; and $15.2 \pm 1.5 \mathrm{ka}$ (UNL-3463) at a depth of about $3.6 \mathrm{~m}$ (Berry and others, 2015a, 2018a). Shovel is 68 centimeters long. Photographs by M.E. Berry, November 2011 and April 2012.

sidestream deposits of Broadway Alluvium overlain by a thin deposit of eolian sand (fig. 6). A buried soil with a clayenriched (Bt) horizon marks the top of the alluvial sequence; a second buried soil with a thin A horizon and weakly developed Bk horizon (stage I carbonate morphology) is present within the alluvial sequence at a depth of about $1.2 \mathrm{~m}$. Sediment sampled just above the second buried soil produced an OSL age estimate of $12.4 \pm 1.1 \mathrm{ka}$ (UNL-3498; Berry and others, 2015a, 2018a). Sediment sampled about $0.7 \mathrm{~m}$ below the top of the second buried soil produced an OSL age estimate of

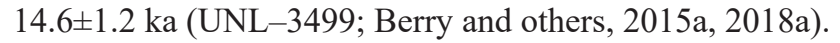
These age estimates are in good agreement with those from the Kiowa Creek site and indicate that aggradation of sidestream Broadway Alluvium could have still been underway about $12 \mathrm{ka}$. The ages also allow for the possibility that the surface was abandoned shortly thereafter.

\section{Narrows Site}

The Narrows site is located on a small tributary stream that cuts a Qa3 (Kuner) terrace on the north side of the South Platte River valley near the Narrows on the Weldona quadrangle (fig. 2; Berry and others, 2018b). The stream cut exposes about $4.8 \mathrm{~m}$ of Qa3 terrace alluvium overlying mainstream deposits of Broadway Alluvium (fig. 7). Pierre Shale crops out upstream (to the north) and beneath Broadway Alluvium a short distance downstream (to the south) of this exposure.

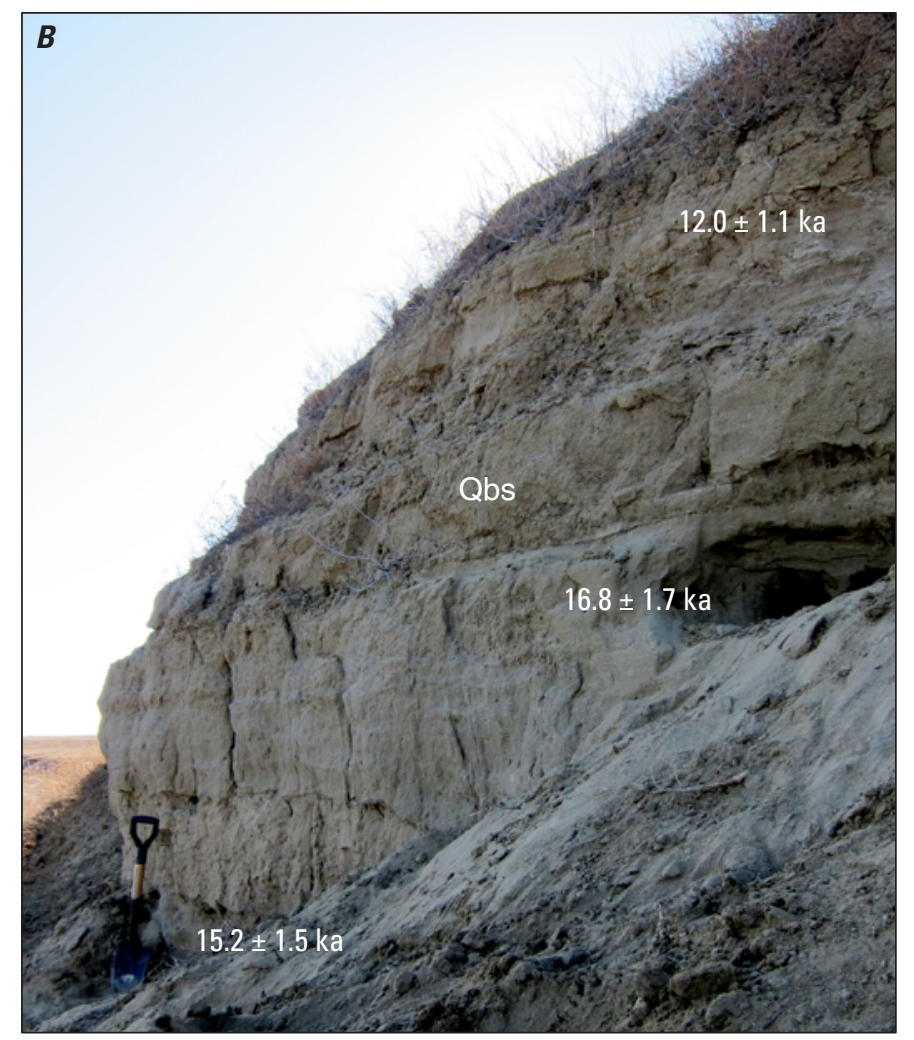

The Qa3 terrace alluvium includes deposits of sheetwash and colluvium interbedded with river alluvium near the valley sides (Berry and others, 2018b). At the Narrows exposure, the section can be divided into two packets based on sediment characteristics. The lower packet is made up of light olive brown to grayish brown clayey silt interstratified with light yellowish-brown silt, clayey silt, and sand with few scattered small pebbles (fig. 7). In comparison, the upper packet is sandier and generally lacks the light olive brown to grayishbrown clayey silt layers characteristic of the lower packet. It is mostly made up of light yellowish-brown, weakly stratified silt, clayey silt, sand, and pebbly sand with interspersed granule to small pebble stringers and coarse sand lenses.

The lower Qa3 packet contained probable Succinea snail shells. Two shells, collected near the bottom and top of the lower packet, were submitted for radiocarbon dating and had age estimates that calibrate to $11.90 \pm 0.28 \mathrm{cal} \mathrm{ka}$ B.P. $\left(10.22 \pm 0.07{ }^{14} \mathrm{C}\right.$ ka B.P., Aeon-994) and $11.95 \pm 0.24 \mathrm{cal}$ ka B.P. (10.24 $\pm 0.06{ }^{14} \mathrm{C}$ ka B.P., Aeon-995), respectively (fig. 7; Berry and others, 2015a, 2018a). The ages are reversed stratigraphically, but the age difference is very small and within the limits of error. Based on the ages, the lower packet of sediment could have been deposited over a short period of time during the latest Pleistocene or earliest Holocene. The light olive brown to grayish brown clayey silt layers could reflect relatively high influx of sediment derived from Pierre Shale bounding the northern South Platte valley margin, immediately after 


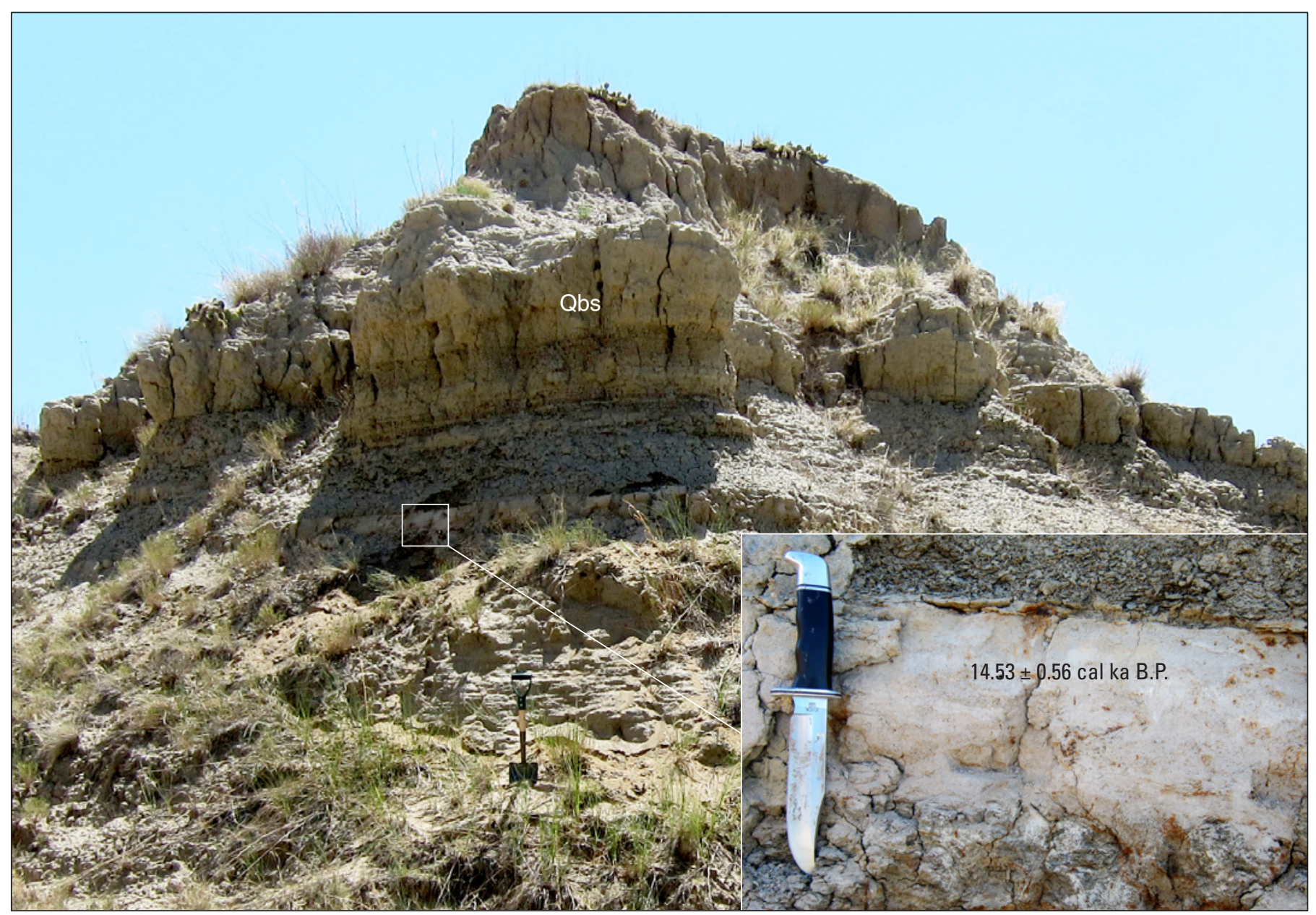

Figure 5. South Platte River bluff site in the South Platte River corridor, northeastern Colorado. Qbs, sidestream deposits of Broadway Alluvium. Uppermost deposits of Qbs have been eroded from section visible in this photograph but are present in nearby exposures where about 0.5 meter $(\mathrm{m})$ of eolian sand overlies the alluvial section. Inset photograph shows close-up view of 15-centimeter (cm)-thick silt bed containing probable Succinea snail shells; silt bed is at a depth of about $3.7 \mathrm{~m}$ in the total section (Gardner, 1967). Four small shells combined for dating had an estimated age of $14.53 \pm 0.56$ calibrated thousand years before present (Aeon-1064; Berry and others, 2015a, 2018a). Shovel is $68 \mathrm{~cm}$ long. Knife is $26 \mathrm{~cm}$ long. Photographs by M.E. Berry, July 2012.

cessation of river incision that formed the higher, Kersey (Broadway) terrace.

A layer of very fine sand in the upper Qa3 packet was sampled for OSL dating from a site roughly $10 \mathrm{~m}$ north (upstream) from where the snail shells were collected. The sample was collected at a depth of about $3.5 \mathrm{~m}$, inferred to be near the base of the upper packet based on thicknesses seen in the downstream exposure. Its exact position within the upper packet could not be determined, however, because the section beneath where the OSL sample was taken was covered by a thick wedge of colluvium. The OSL analysis produced an age estimate of $9.1 \pm 0.9 \mathrm{ka}$ (UNL-3503; Berry and others, 2015a, 2018a), which is several thousand years younger than calibrated ${ }^{14} \mathrm{C}$ ages of snails from the lower packet. This younger age could reflect an actual age difference between upper and lower sediment packets or be a byproduct of using two different dating methods. Regardless, the OSL date supports the idea that deposition of Qa3 terrace alluvium was underway in the early Holocene and leaves open the possibility that it started as early as the latest Pleistocene.

Mainstream Broadway Alluvium was sampled for OSL dating at the Narrows site (fig. 7), and at another site (TK-R in Berry and others, 2015a) located along the South Platte River bluff about $0.8 \mathrm{~km}$ upstream from the Kiowa Creek site (fig. 2), where mainstream Broadway Alluvium is overlain by about $7 \mathrm{~m}$ of sidestream Broadway Alluvium. Samples from the two sites produced OSL ages of $8.0 \pm 0.7 \mathrm{ka}$ (UNL-3502, Narrows site) and 9.4 $\pm 1.0 \mathrm{ka}$ (UNL-3504, TK-R site, Berry and others, 2015a, 2018a), which are reasonably similar to one another (overlapping at $\pm 1 \sigma$ ), but for unknown reasons, are anomalously younger than and stratigraphically inconsistent with all ages obtained for deposits that overlie them at 


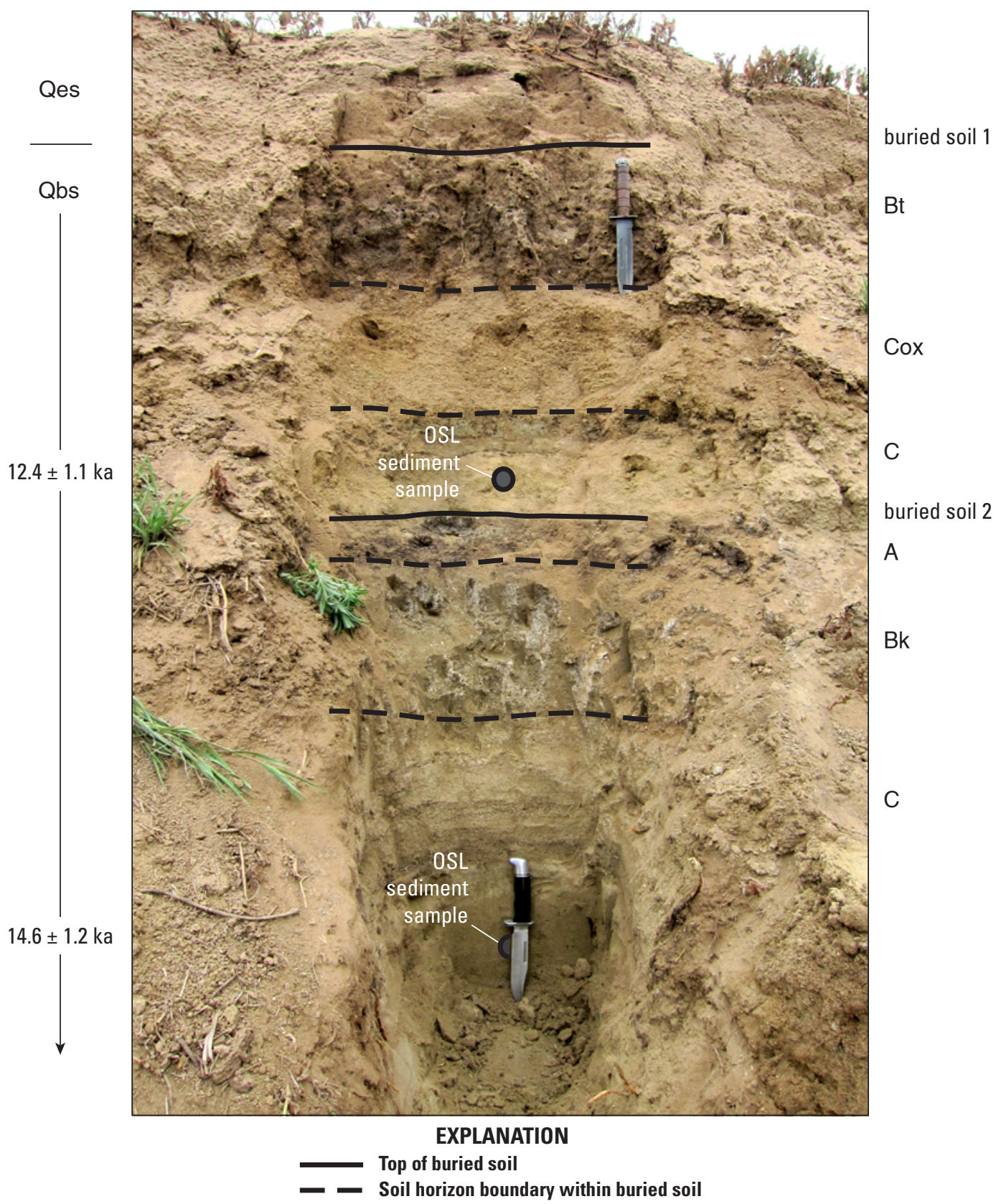

Figure 6. Bijou Creek site in the South Platte River corridor, northeastern Colorado. Exposure is at the edge of a terrace made up of sidestream deposits of Broadway Alluvium (Qbs); overlain by a thin deposit of eolian sand (Qes). Buried soil 1 marks top of Qbs alluvium; buried soil 2 differentiates an older packet of Qbs deposits within the sequence. Sediment sampled at a depth of about 1.1 meters $(\mathrm{m})$ (gray-filled circle) just above buried soil 2 has an optically stimulated luminescence (OSL) age estimate of $12.4 \pm 1.1$ thousand years (ka) (UNL-3498; Berry and others, 2015a, 2018a). Sediment sampled at a depth of about $1.9 \mathrm{~m}$ (gray-filled half circle behind lower knife;

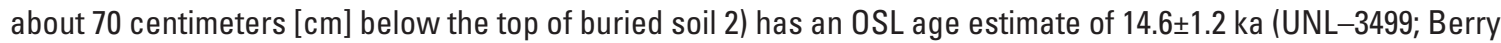
and others, 2015a, 2018a). Bt, clay-enriched horizon; Cox, oxidized parent material; A, organic-rich horizon; Bk, carbonate-enriched horizon (stage I carbonate morphology); $C$, mostly unaltered parent material. Solid lines mark the tops of the buried soils; dashed lines mark soil horizon boundaries within the buried soils. Lower knife is $26 \mathrm{~cm}$ long. Photograph by M.E. Berry, May 2012. 


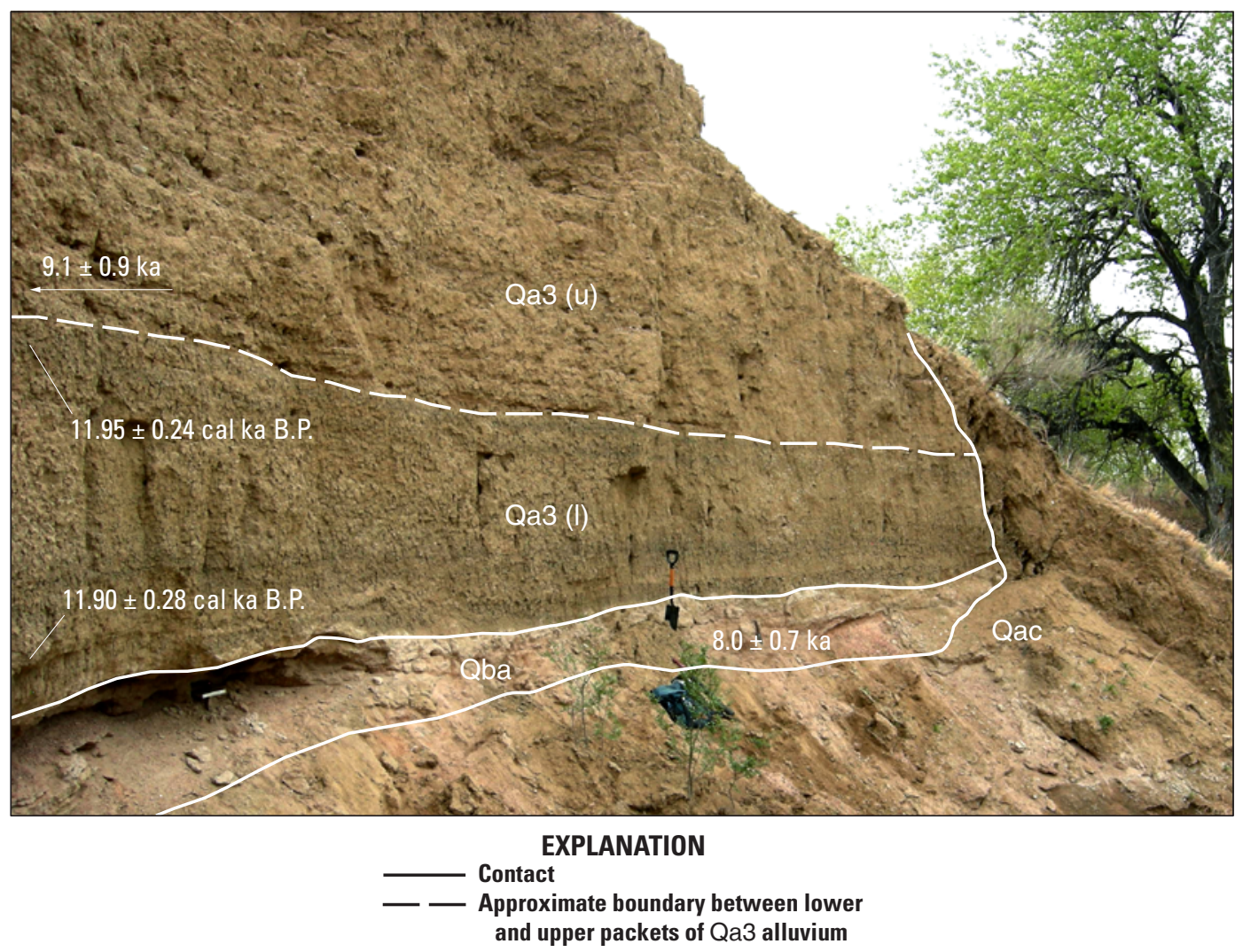

Figure 7. Narrows site in the South Platte River corridor, northeastern Colorado. Qba, mainstream deposits of Broadway Alluvium; Qa3 (I), lower packet of Qa3 terrace alluvium; Qa3 (u), upper packet of Qa3 terrace alluvium; Qac, colluvium. Two probable Succinea snail shells collected near the bottom and top of the lower packet (locations shown are approximate) had calibrated radiocarbon ages of $11.90 \pm 0.28$ calibrated thousand years before present (cal ka B.P.) (Aeon-994) and $11.95 \pm 0.24 \mathrm{cal}$ ka B.P. (Aeon-995) respectively (see Berry and others, 2015a, 2018a). Sediment sampled from the upper packet at a site roughly 10 meters to the north (left of photo) had an optically stimulated luminescence (OSL) age estimate of $9.1 \pm 0.9$ thousand years ( $\mathrm{ka}$ ) (UNL-3503; Berry and others, 2015a, 2018a). Oba sediments collected near the shovel had an OSL age estimate of $8.0 \pm 0.7 \mathrm{ka}$ (UNL-3502), which is anomalously younger than and stratigraphically inconsistent with all ages obtained for overlying deposits and is therefore not considered a realistic estimate for the age of mainstream Broadway Alluvium (Berry and others, 2015a, 2018a). Shovel is 68 centimeters long. Photograph by J.L. Slate, April 2012.

those sites; therefore, these ages are not considered realistic estimates for the age of Broadway Alluvium. Data from other sites (previously discussed) indicate that the upper 2-4 m of sidestream Broadway Alluvium was probably deposited between about $17-15 \mathrm{ka}$ and $12 \mathrm{ka}$, which is likely comparable to the deposition age of the uppermost section of mainstream Broadway Alluvium (best preserved near Masters; fig. 2).

\section{Timing of Kersey (Broadway) Terrace Formation}

Age estimates for deposits along this part of the South Platte River corridor indicate that sidestream deposits of Broadway Alluvium could have still been actively accumulating about $12 \mathrm{ka}$, but the age estimates also allow for aggradation to have ceased and the surface to have been abandoned shortly thereafter as the river incised to form the
Kersey (Broadway) terrace. Age estimates and archaeological data associated with mainstream Broadway Alluvium at other sites are generally consistent with this scenario. Near Masters (fig. 2), a ${ }^{230} \mathrm{Th} / \mathrm{U}$ age estimate of $11.0 \pm 1.1 \mathrm{ka}$ (EF-Wp67-1, Paces, 2015; Berry and others, 2018a) for a thin coat of pedogenic carbonate on a bone fragment from uppermost Broadway Alluvium supports surface stabilization and the onset of soil development at that site sometime prior to about $11 \mathrm{ka}$. Similarly, near Kersey, Colo. (fig. 1), the presence of Clovis artifacts in uppermost Broadway Alluvium and Folsom-age material in overlying sand dunes led Holliday (1987) to conclude that Broadway Alluvium was still accumulating about 13 ka B.P. (11.5-11 ka B.P. uncalibrated radiocarbon years) but that aggradation had ceased and the surface was stabilized no later than about 11.5 ka B.P. (10 ka B.P., uncalibrated radiocarbon years). 


\section{Nature of Late Pleistocene-Holocene Transition}

In canyons of the Colorado Front Range, net river incision has been linked to transitions from glacial to interglacial conditions (Schildgen and others, 2002), which is consistent with this study's findings along the stretch of South Platte River between Masters and Fort Morgan. The river incision that resulted in abandonment of the Kersey (Broadway) level at the end of Pinedale deglaciation appears to have occurred over a very short period and been notable in scale; near the Narrows site, the river downcut as much as $15 \mathrm{~m}$ (fig. 8) through sandy Broadway Alluvium before renewed aggradation resulted in deposition of the next lower alluvium (Qa3 or Kuner terrace alluvium). Calibrated radiocarbon ages for Succinea snail shells collected from the lower packet of Qa3 deposits (fig. 7), indicate that river incision into the Broadway Alluvium could have been completed and aggradation renewed by about $11.95-11.90 \mathrm{ka}$. When combined with the inferred timing of abandonment of the Kersey (Broadway) river level sometime after about $12 \mathrm{ka}$, these ages imply that the $15 \mathrm{~m}$ of incision could have been accomplished very rapidly, possibly within a few hundred years or less. These findings are generally consistent with work presented in McFaul and others (1994) and Haynes and others (1998) that also supports rapid downcutting from Kersey to Kuner levels, and with an age reported in Haynes and others (1998) of about $11.68 \pm 0.36 \mathrm{cal}$ ka B.P. $\left(10.11 \pm 0.09{ }^{14} \mathrm{C}\right.$ ka B.P., AA-11084A) for humic acids in charcoal from Kuner terrace alluvium at the Bernhardt site, outside of the study area located roughly $80 \mathrm{~km}$ west of the Narrows site (fig. 1). Foster and others (2016) argue for a conceptual model for Front Range rivers that includes brief episodes of rapid incision.

If the changes in the fluvial system-from long-term aggradation of Broadway Alluvium - to incision resulting in formation of the Kersey (Broadway) terrace - to renewed aggradation that resulted in deposition of basal Qa3 (or Kuner) terrace alluvium - did occur between about $12 \mathrm{ka}$ and $11.9 \mathrm{ka}$, the changes could be related to the Younger Dryas climate event, which in the Northern Hemisphere was a brief cold period between approximately 12.9 and $11.7 \mathrm{ka}$ B.P. (calendar years) that interrupted the transition to a warmer climate at the end of the last glaciation (Rasmussen and others,

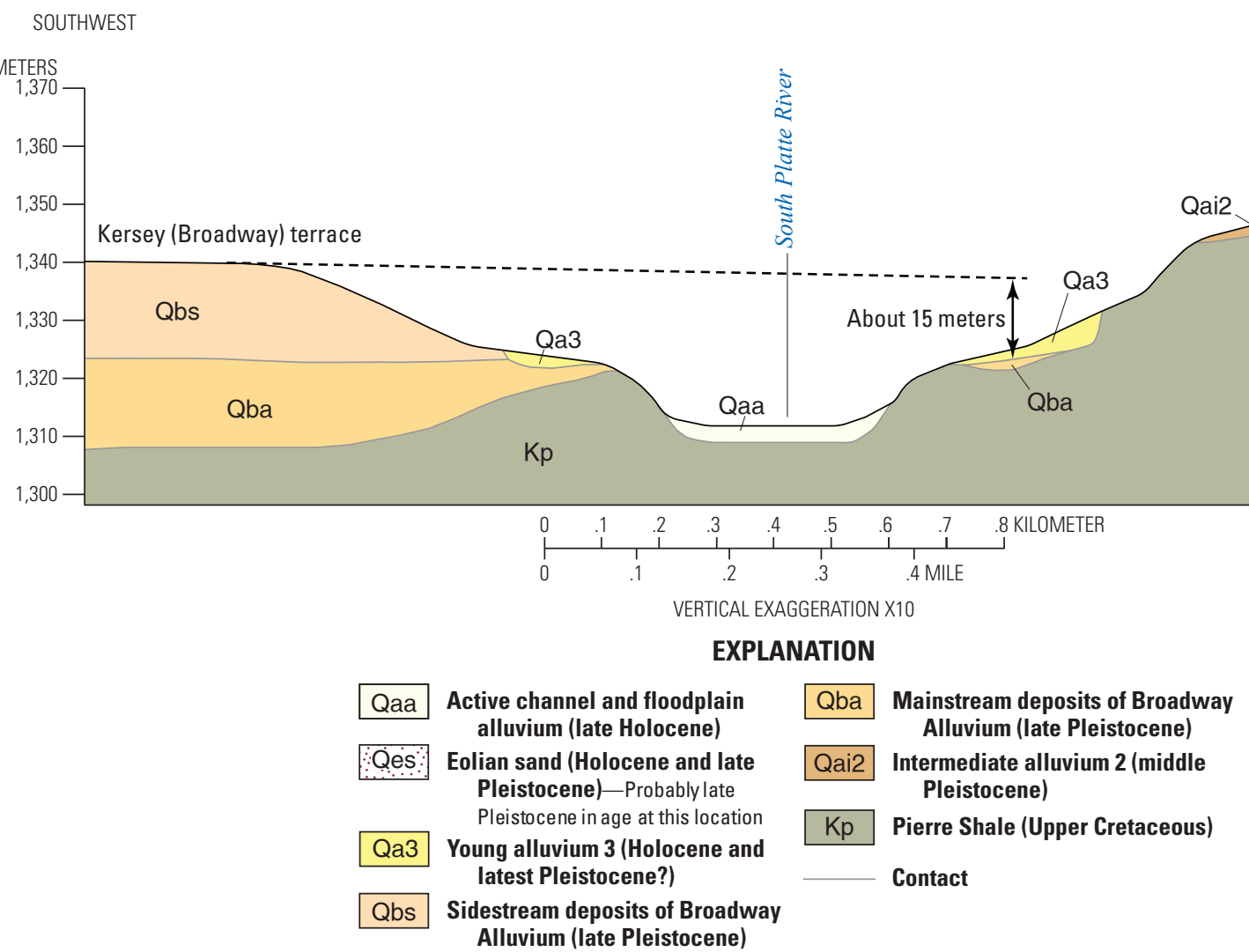

Figure 8. Schematic cross section across the South Platte River, near the Narrows site in the South Platte River corridor, northeastern Colorado. The middle Pleistocene Louviers Alluvium underlies mainstream and sidestream deposits of Broadway Alluvium roughly two miles to the southwest (to the left) of section. Field relations indicate that after the South Platte River abandoned the Kersey (Broadway) level about 15 meters of net incision occurred at the Narrows site before renewed aggradation resulted in deposition of the Qa3 (Kuner) terrace alluvium. 
2006; Carlson, 2013). A return to a cooler climate could have increased stream discharge and therefore stream power (Bull, 1990), and with a return of glacial activity in the mountains, potentially reduced sediment supply to this part of the South Platte River. Together, these types of changes could have resulted in river incision and could have been followed by renewed deposition as transition to a warmer climate resumed. Haynes and others (1998) also report a possible tie between river processes and the Younger Dryas event although they attribute quasi-river stability at the Kuner level to the climatic event. Their interpretation is based on uncalibrated ages for both Kuner terrace alluvium and the Younger Dryas event. Calibrated ages imply that the quasi-river stability they invoke for the Kuner level post-dates the Younger Dryas event, and therefore the Younger Dryas event may more closely correspond to the time of downcutting from Kersey to Kuner levels. The latter scenario would be consistent with data presented in this report. There is evidence in the Front Range for a Younger Dryas event (see Menounos and Reasoner, 1997) and the Satanta Peak moraines probably record that (Benedict, 1973, 1985). But Muhs and others (1999a) note that carbon isotope data do not indicate cooler conditions in eastern Colorado during the Younger Dryas climate event. Therefore, it is uncertain how much influence this climatic event may have had on river processes in northeastern Colorado.

Alternatively, changes in the fluvial system could have been a complex response to crossing a geomorphic threshold (Schumm, 1973) during the final phases of Pinedale deglaciation. In this scenario, incision would have initiated at the point when sediment load being delivered to the river system was no longer sufficient to sustain the Kersey (Broadway) river level, and the system readjusted by downcutting rapidly. Renewed aggradation resulting in deposition of Qa3 alluvium could have been part of a complex response in a sequence of events wherein the incision, propagating upstream, created a new sediment supply that was transported and deposited downstream (Schumm, 1973). Lindsey and others (2005) propose this type of complex response to explain their observations on the South Platte River just east of the Front Range in the Denver metropolitan area. In cross sections, they similarly show up to 15-20 $\mathrm{m}$ of incision following abandonment of the Broadway surface, which was followed by deposition of a basal gravel that they consider to be latest Pleistocene (late Broadway) in age based on the size of gravel in the deposit (for example, see cross sections $L-L^{\prime}$ and $O-O^{\prime}$ of Lindsey and others, 2005). They interpret the basal gravel as lag from when downcutting ceased. The basal gravel is in conformable contact with an overlying sandy gravel they consider to be Pleistocene-Holocene or Holocene in age, and whose deposition they attribute to a complex response of the river system. Their scenario is generally similar to what this study documents along the river corridor in northeastern Colorado; Qa3 deposits exposed at the Narrows site are fine grained, but elsewhere along this part of the river corridor they include pebbly sand, sandy pebble gravel, or cobble gravel (Berry and others, 2018b, c) locally exposed in conformable contact with overlying sand and pebbly sand deposits. The primary difference between the two scenarios is that in the present study area, the Qa3 deposits have been subsequently incised to form the Qa3 (Kuner) terrace, whereas in the study area of Lindsey and others (2005), the deposits have not been incised and are part of what they consider the modern valley fill.

\section{River Activity in the Early Holocene}

Radiocarbon and OSL ages obtained at the Narrows site (fig. 7) indicate that deposition of Qa3 (Kuner) terrace alluvium could have begun in latest Pleistocene or early Holocene and was still in progress around $9 \mathrm{ka}$. The timing of Qa3 surface stabilization, which could have been relatively close in time to when the surface was abandoned due to river incision, can be estimated from ages from other sites and soils data. Near Masters, McFaul and others (1994) obtained an age of about $5.84 \pm 0.18 \mathrm{cal}$ ka B.P. $\left(5.12 \pm 0.08{ }^{14} \mathrm{C}\right.$ ka B.P., Beta-42564) for soil humate from a buried A horizon developed on Qa3 terrace alluvium and subsequently buried by eolian sand. This is a minimum-limiting age for stabilization of the Qa3 surface, because ages on buried A horizons estimate only when burial prevented the horizon from further accumulation of organic material. McFaul and others (1994) use this radiocarbon age, the degree of development of the associated buried soil profile, and timing of mountain glaciations of Benedict (1985) to suggest that the surface could have been stabilized by about 8-7 cal ka (7.25-6.38 ka B.P. uncalibrated radiocarbon years). Similarly, Berry and others (2018b, c) obtained a radiocarbon age of $4.92 \pm 0.07 \mathrm{cal}$ ka B.P. $\left(4.36 \pm 0.03{ }^{14} \mathrm{C}\right.$ ka B.P., Aeon-2101) for a buried A horizon developed on Qa3 terrace alluvium of Wildcat Creek, a tributary to the South Platte River (fig. 2). Here, the profile includes a weakly developed Bt horizon roughly $35 \mathrm{~cm}$ thick and filamentous stage I carbonate accumulation, which most likely indicates several thousand years of soil development on the terrace surface prior to its burial by sheetwash deposits about $4.9 \mathrm{cal} \mathrm{ka}$. The degree of development of the buried profile combined with the radiocarbon age at this site also permit an interpretation of surface stabilization and onset of soil development by about 8-7 cal ka, or earlier. Stabilization of the Qa3 surface by about the beginning of the middle Holocene (suggested as 8.2 ka by Walker and others, 2012b) is supported by surface soils on the Qa3 terrace, which are characterized by a clay-enriched (Bt) horizon and weakly developed Bk horizon with stage I-II carbonate morphology (U.S. Department of Agriculture Natural Resources Conservation Service, 2009a, b). These soils are close in development to those on the Kersey (Broadway) terrace (Berry and others, 2015a, b; 2018b, c), suggesting that the age difference between surfaces is relatively small. 


\section{Late Holocene Terrace and Gully Formation}

Since the time of incision that formed the Qa3 (Kuner) terrace, the South Platte River has apparently maintained a relatively stable position on its valley floor. Two low terraces, 1.5-3 $\mathrm{m}$ above the floodplain and occasionally flooded at least in part by the modern river regime, are probably late Holocene in age based on weak soil development (U.S. Department of Agriculture Natural Resources Conservation Service, 2009a, b; Berry and others, 2015a, b; 2018b, c). These terraces may record near-equilibrium of the river, as Lindsey and others (2005) invoke for reaches of the South Platte River just east of the Front Range in the Denver metropolitan area. Nonetheless, a period of rapid incision during historical times is recorded in tributary drainages north of the South Platte River downstream from the Narrows.

\section{Paleovalley Site}

In the study area, headward erosion is common within tributary drainages and small sediment-filled gullies that drain the north side of the South Platte River downstream from the Narrows. Recent incision has formed gullies 2-3 m deep in the Narrows area, but in tributary drainages throughout the upper reaches of Wildcat Creek, ephemeral, headward-eroding gullies 5-6 m deep are prevalent. Comparison of satellite imagery dated October 9, 1989 and June 14, 2016, viewed with Google Earth, indicates that gullies in the Wildcat Creek drainage have been eroding headward at highly variable rates during that 27-year period, with estimated rates ranging from about $0.1-2$ meters per year (m/yr).

The gullies in the Wildcat Creek drainage expose 4-5 m or more of sediment filling paleovalleys underlain by Pierre Shale (figs. 9, 10; Berry and others, 2018c). The paleovalley fill (Qlg) is primarily made up of alluvial sands and gravels overlain by sands and silts that were probably originally deposited by eolian processes but later partly reworked by sheetwash processes. A middle Pleistocene age is indicated by an eroded pedogenic carbonate horizon with stage III morphology at the contact between the paleovalley fill and the sediments that unconformably overlie it (fig. 10B; Berry and others, 2018c). The overlying deposits, typically about $1-1.5 \mathrm{~m}$ thick, are made up of weakly stratified silt with scattered, poorly sorted sand stringers. Soil development is minimal, indicating a young age for the deposits. This uppermost section is interpreted as latest Holocene sheetwash deposits (Qay) derived primarily from the reworking of late Pleistocene and possibly Holocene loess and lesser amounts of eolian sand that blanket the low drainage divides (Berry and others, 2018c). These sediments underlie distinctive, flat-floored valleys most notable near the heads of the drainages, which have been entrenched as much as 5-6 m by steep-walled, headward-eroding gullies (fig. 9). A bison tooth and several bones that likely are bison were collected at a depth of about $0.9-1.2 \mathrm{~m}$ from young sheetwash deposits in one of the gully headcuts (Paleovalley site; figs. 2, 10). The tooth has a radiocarbon age of about $0.13 \mathrm{cal}$ ka B.P. $\left(0.11 \pm 0.02{ }^{14} \mathrm{C}\right.$ ka B.P., Aeon-1582), which indicates that it could date to the early 1820s (Berry and others, 2018a, c). Based on this age estimate, the valley floor at this site aggraded about one meter and then was entrenched by as much as 5-6 m, possibly over the last 190-200 years.

\section{Tributary Aggradation and Incision During the Latest Holocene}

Deposits exposed in gully cuts indicate a long history of valley cutting and filling in the tributaries to Wildcat Creek. Reasons for recent aggradation could be complex but based on the age of the bison tooth, probably include drought as a contributing factor. Tree ring records indicate widespread drought on the Great Plains during the 19th century, most notably around 1820 and in the early 1860s (Meko, 1992), and a more locally focused but severe and persistent drought in eastern Colorado about 1845-1856 (Woodhouse and Brown, 2001; Woodhouse and others, 2002). Historical observations document active sand dunes on the Great Plains during these times of drought (Muhs and Holliday, 1995), implying sparse vegetation on the landscape. Without vegetation to stabilize sediments on low drainage divides, sediments would have been prone to erosion and more easily redistributed to valley floors.

Subsequent entrenchment of valley floors also could be due to a complex set of factors. Similar gully headcut erosion within the South Platte River drainage system has been studied in detail at a site south of Strasburg, Colo., roughly $100 \mathrm{~km}$ southwest of the study area (Rengers and Tucker, 2014, 2015; Rengers and others, 2016). Results from that study indicate intrinsic geomorphic instabilities are primary in causing the initiation of headcuts, which develop because of focused scour during flash floods in areas where ground cover is inadequate to resist erosion. Because vegetation is a key factor, droughtinduced changes in vegetation cover could play an important role in gully incision and headward erosion (Rengers and others, 2016) especially at times immediately following a drought. The general similarity between field sites suggests that these same factors are important here as well.

An additional factor for gully incision and headward erosion could be like that invoked for historical arroyo cutting in the American Southwest. This arroyo cutting was initiated mostly in the 1880s through early 1900s (Aby, 2017), but has been less active and characterized by mostly headward erosion of existing gullies since about 1915 (Cooke and Reeves, 1976). It is likely multiple factors contributed to historical arroyo incision in the American Southwest including climatic changes and grazing of livestock that affected vegetation cover (Cooke and Reeves, 1976). Nevertheless, recent research indicates a common factor that at least partly caused or exacerbated arroyo incision was the construction by early settlers of features that concentrated drainage (Aby, 2017). These 

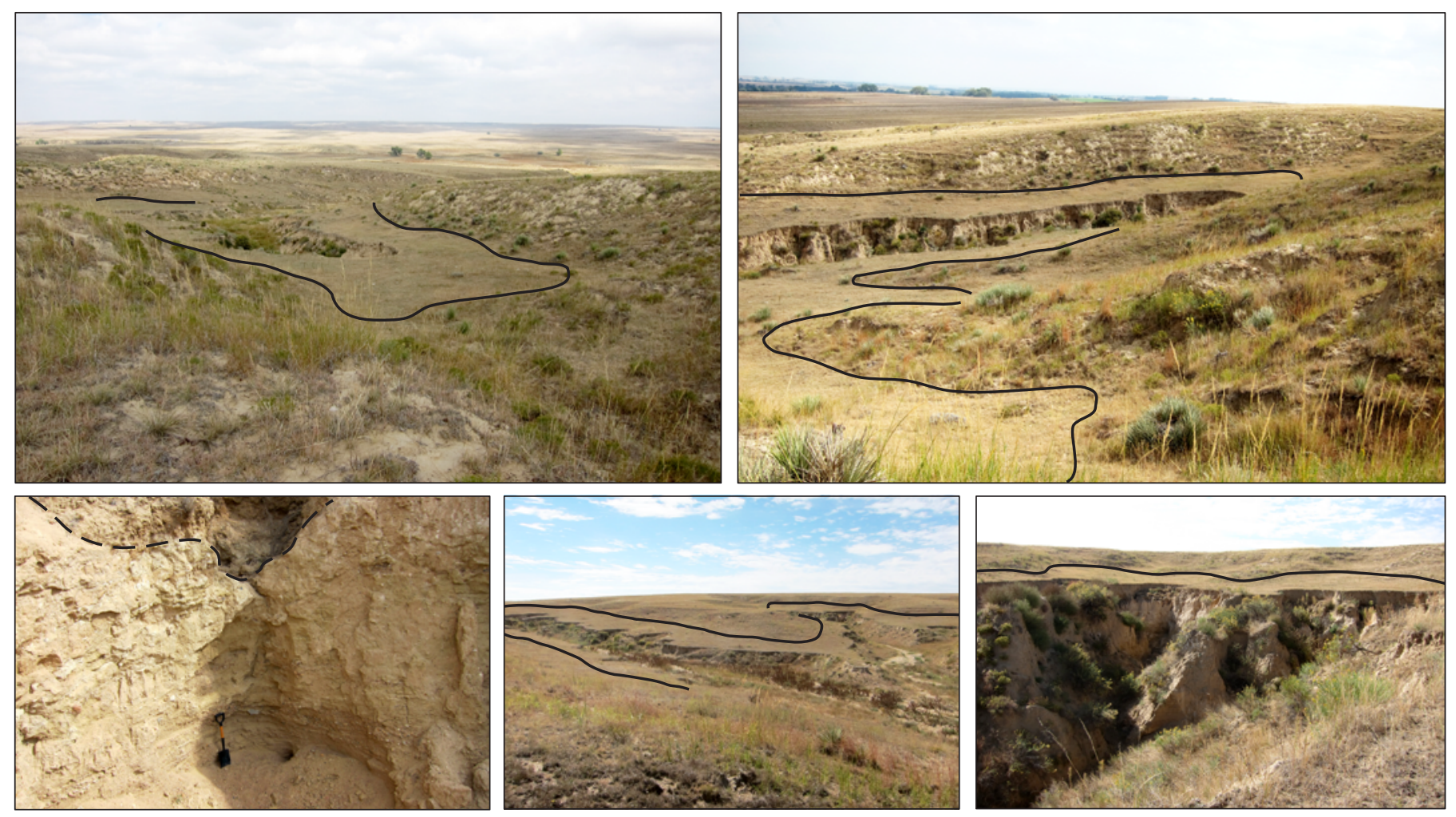

\section{EXPLANATION}

Approximate edge of flat valley floors between low drainage divides made up of loess over Pierre Shale

- Contact between young sheetwash deposits and older paleovalley fill

Figure 9. Examples of flat-floored valleys incised by actively headward-eroding, steep-walled gullies that expose young sheetwash deposits overlying paleovalley fill in the South Platte River corridor, northeastern Colorado. Solid lines approximate edges of flat valley floors between low drainage divides made up of loess over Cretaceous Pierre Shale. Dashed line in lower left photo marks contact between young sheetwash deposits and older paleovalley fill. Shovel is 68 centimeters long. Gully in lower right photo is roughly 5 meters deep. Photographs by M.E. Berry, June 2013 and September 2015.

features include irrigation canals, roads, and railroad embankments (Cooke and Reeves, 1976). In the study area, the first settlers were stockmen who began constructing small irrigation ditches in the 1870s. By the 1880s, major construction of irrigation ditches was underway, railroads were being completed, and by the early 1900s numerous reservoirs were being built (Dille, 1960). Two short-lived reservoirs were constructed on Wildcat Creek during this time, one of which would have had a direct effect on local base level of ephemeral drainages near the bison tooth site (Wildcat Reservoir). The other (Jackpot Reservoir) was located roughly $10 \mathrm{~km}$ upstream from the bison tooth site. Historical newspaper accounts indicate that the reservoir dams on Wildcat Creek were prone to damage during floods (for example, Brush Tribune, 1901, 1902a, 1902b). Dam failure during flood events may have influenced gully erosion near the tooth site, but because these headward-eroding gullies are not unique to Wildcat Creek, local dam failures were most likely not a primary cause.

Another important aspect of irrigation and damming during historical times is that it changed the characteristics of groundwater flow and groundwater-surface water interactions in the region. This change had a dramatic effect on streamflow patterns and morphology of the South Platte River which transformed from a wide, shallow, and sandy braided river that was dry during parts of the year, to a much narrower, deeper river with braided-meandering transition morphology and perennial discharge (Dille, 1960; Williams, 1978; Nadler and Schumm, 1981; Eschner and others, 1983; Harvey and others, 1985). This type of major change to groundwater flow and the hydrologic regime of the South Platte River system since the 1880 s could have contributed to or exacerbated historical gully incision. 


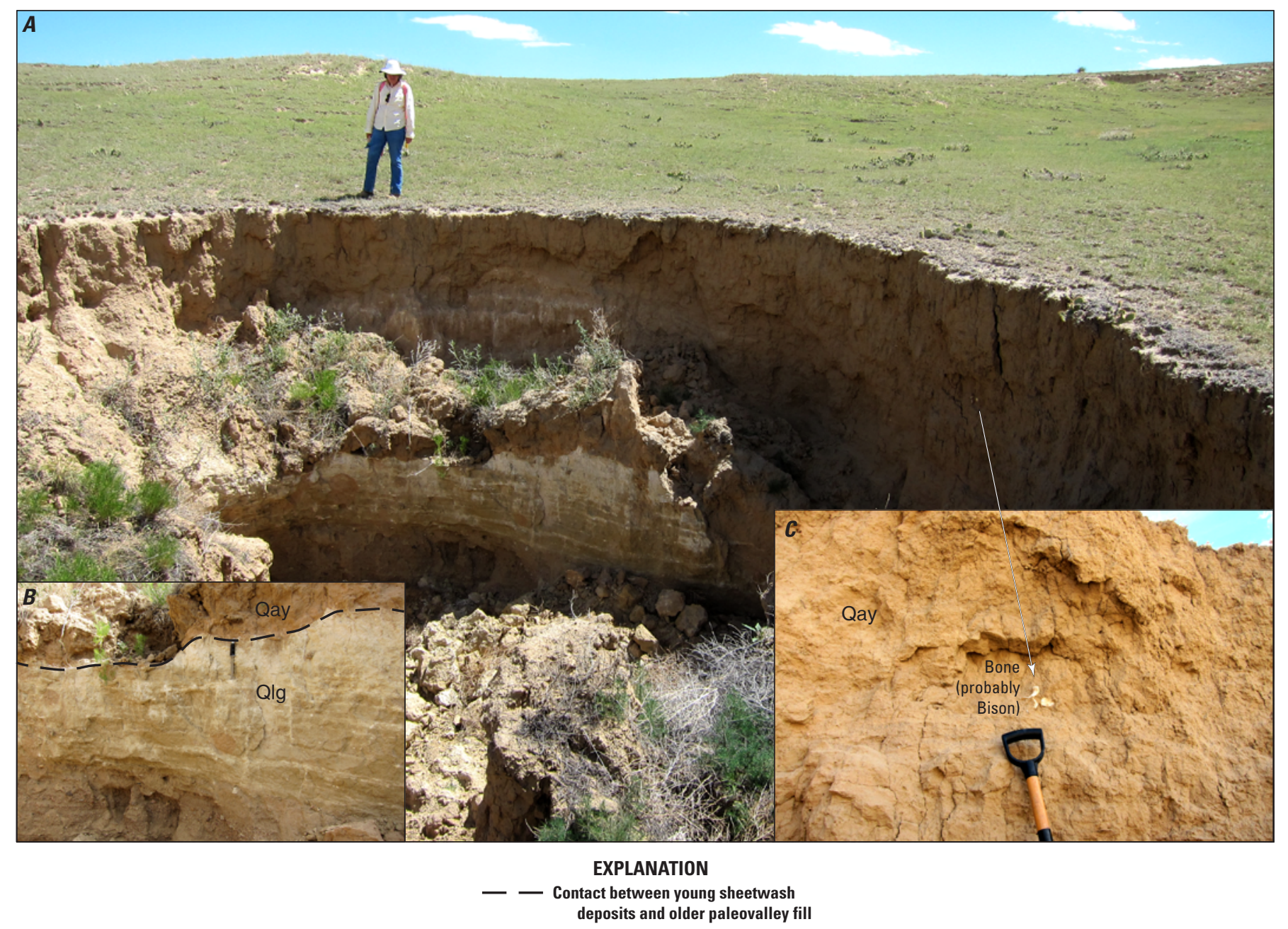

Figure 10. Paleovalley site in the South Platte River corridor, northeastern Colorado. A, Gully headcut exposes paleovalley fill overlain by young sheetwash deposits. Cretaceous Pierre Shale is not exposed here but does crop out beneath paleovalley fill down gully. $B$, Close-up view of slump block at the gully headwall. Dashed line marks erosional contact between young sheetwash deposits (Qay) and paleovalley fill (Qlg). Knife is 26 centimeters (cm) long. C, Close-up view of bones (probably bison) encased in young sheetwash deposits (Qay). The dated bison tooth was uncovered while excavating bones seen in photograph. The tooth has a radiocarbon age of about $0.13 \mathrm{cal}$ ka B.P. $\left(0.11 \pm 0.02{ }^{14} \mathrm{C}\right.$ ka B.P., Aeon-1582), which indicates that it could date to the early $1820 \mathrm{~s}$ (Berry and others, 2018a, c). Shovel handle is $12 \mathrm{~cm}$ wide. Photographs by M.E. Berry, June 2013.

\section{Summary and Geomorphic Implications of River Stratigraphy}

Research carried out for this study combined with previous work described herein indicate that along this stretch of the South Platte River the early Pleistocene and first half of the middle Pleistocene was a time of net incision. Periodically, incision was interrupted by episodes of aggradation, resulting in deposition of alluvium that subsequently formed terrace deposits along the valley sides as net incision resumed. Sometime after about $380 \mathrm{ka}$, based on U-series dating of intermediate alluvium (Qai), the river cut a deep paleovalley that was then filled with a thick sequence of what is inferred to be Louviers Alluvium. Deep entrenchment below present grade followed by deposition of Louviers Alluvium was also noted by Bryan and Ray (1940) in the Kersey area. Continued net aggradation of the South Platte River during the late Pleistocene buried the Louviers paleovalley with a thick sequence of Broadway Alluvium. At the end of the late Pleistocene, incision of the river valley caused the Broadway level to be abandoned and resulted in formation of the Kersey (Broadway) terrace, whose riser forms a prominent bluff along the south side of the river. The river incised to a position within several meters of modern stream level before renewed aggradation resulted in deposition of 5-6 $\mathrm{m}$ of latest Pleistocene(?) and Holocene alluvium (Qa3). The last episode of notable incision, when the river incised to a position close to modern stream level, could have started around the beginning of the middle Holocene (about $8 \mathrm{ka}$ ) and resulted in abandonment of the Qa3 
level to form the Kuner terrace. Low terraces on the valley floor could indicate that during the late Holocene, the river has been approaching equilibrium conditions, with the river primarily cutting and backfilling laterally across valley rather than incising (see Lindsey and others, 2005).

Interpretations of landscape development from this study suggest that the South Platte River in northeastern Colorado was likely very sensitive to rapidly changing environmental conditions or crossed threshold conditions that triggered rapid geomorphic response during major climate changes associated with the late Pleistocene-Holocene transition. Historical times were also marked by rapid incision, reflected by gully incision and headward erosion in tributary valleys draining the north side of the South Platte River. This historical erosion could be related at least in part to extensive construction of irrigation ditches and reservoirs in the late 1800s-early 1900s, which altered drainage paths and groundwater flow and could have amplified natural factors such as climate change or intrinsic geomorphic instabilities within the system.

\section{References Cited}

Aby, S.B., 2017, Date of arroyo cutting in the American Southwest and the influence of human activities: Anthropocene, v. 18, p. 76-88, accessed August 2018, at https://doi.org/10.1016/j.ancene.2017.05.005.

Aleinikoff, J.N., Muhs, D.R., Sauer, R.R., and Fanning, C.M., 1999, Late Quaternary loess in northeastern Colorado-Part $\mathrm{II}-\mathrm{Pb}$ isotopic evidence for the variability of loess sources: Geological Society of America Bulletin, v. 111, no. 12, p. 1876-1883. [Also available at https://doi.org/10.1130/00167606(1999)111<1876:LQLINC>2.3.CO;2.]

Barendregt, R.W., and Duk-Rodkin, A., 2011, Chronology and extent of late Cenozoic ice sheets in North America-A magnetostratigraphical assessment, chap. 32, of Quaternary glaciations, Extent and chronology-A closer look: Developments in Quaternary Science, v. 15, p. 419-426, accessed August 2018, at https://doi.org/10.1016/B978-0-444-534477.00032-5.

Bell, C.J., Lundelius, E.L., Jr., Barnosky, A.D., Graham, R.W., Lindsay, E.H., Ruez, D.R., Jr., Semken, H.A., Jr., Webb, S.D., and Zakrzewski, R.J., 2004, The Blancan, Irvingtonian, and Rancholabrean mammal ages, in Woodburne, M.O., ed., Late Cretaceous and Cenozoic mammals of North America-Biostratigraphy and geochronology: New York, Columbia University Press, p. 232-313.

Benedict, J.B., 1973, Chronology of cirque glaciation, Colorado Front Range: Quaternary Research, v. 3, p. 584-599. [Also available at https://doi.org/10.1016/0033-5894(73)90032-X.]
Benedict, J.B., 1985, Arapaho Pass-Glacial geology and archaeology at the crest of the Colorado Front Range: Ward, Colo., Center for Mountain Archaeology, Research Report 3, 197 p.

Benson, L., Madole, R.F., Kubik, P., and McDonald, R., 2007, Surface-exposure ages of Front Range moraines that may have formed during the Younger Dryas, $8.2 \mathrm{cal} \mathrm{ka}$, and Little Ice Age events: Quaternary Science Reviews, v. 26, no. 11-12, p. 1638-1649. [Also available at https://doi.org/10.1016/j.quascirev.2007.02.015.]

Benson, L., Madole, R.F., Landis, G., and Gosse, J., 2005, New data for late Pleistocene Pinedale alpine glaciation from southwestern Colorado: Quaternary Science Reviews, v. 24, no. 1-2, p. 49-65. [Also available at https://doi.org/10.1016/j.quascirev.2004.07.018.]

Benson, L., Madole, R.F., Phillips, W., Landis, G., Thomas, T., and Kubik, P., 2004, The probable importance of snow and sediment shielding on cosmogenic ages of north-central Colorado Pinedale and pre-Pinedale moraines: Quaternary Science Reviews, v. 23, no. 1-2, p. 193-206. [Also available at https://doi.org/10.1016/j.quascirev.2003.07.002.]

Berry, M.E., Hanson, P.R., Paces, J.B., Taylor, E.M., and Slate, J.L., 2018a, Data release of OSL, 14C, and U-series age data supporting geologic mapping along the South Platte River corridor in northeastern Colorado: U.S. Geological Survey data release, accessed February 2018, at https://doi.org/10.5066/F7QN65M3.

Berry, M.E., Slate, J.L., Hanson, P.R., and Brandt, T.R., 2015a, Geologic map of the Orchard 7.5' quadrangle, Morgan County, Colorado: U.S. Geological Survey Scientific Investigations Map 3331, 1 sheet, 1:24,000, accessed June 2015, at http://dx.doi.org/10.3133/sim3331.

Berry, M.E., Slate, J.L., Paces, J.B., Hanson, P.R., and Brandt, T.R., 2015b, Geologic map of the Masters 7.5' quadrangle, Weld and Morgan Counties, Colorado: U.S. Geological Survey Scientific Investigations Map 3344, 10 p. appendix, 1 sheet, 1:24,000, accessed September 2015, at https://doi. org/10.3133/sim 3344 .

Berry, M.E., Taylor, E.M., Slate, J.L., Paces, J.B., Hanson, P.R., and Brandt, T.R., 2018b, Geologic map of the Weldona 7.5' quadrangle, Morgan County, Colorado: U.S. Geological Survey Scientific Investigations Map 3396, 1 sheet, 1:24,000, accessed March 2018, at https://doi.org/10.3133/ $\operatorname{sim} 3396$.

Berry, M.E., Taylor, E.M., Slate, J.L., Paces, J.B., Hanson, P.R., and Brandt, T.R., 2018c, Geologic map of the Fort Morgan 7.5' quadrangle, Morgan County, Colorado: U.S. Geological Survey Scientific Investigations Map 3408, 2 sheets, 1:24,000, accessed June 2018, at https://doi.org/10.3133/sim3408. 
Birkeland, P.W., Miller, D.C., Patterson, P.E., Price, A.B., and Shroba, R.R., 1996, Soil-geomorphic relationships near Rocky Flats, Boulder and Golden, Colorado area, with a stop at the pre-Fountain Formation paleosol of Wahlstrom (1948): Colorado Geological Survey Open-File Report OF-96-04-27, Field Trip No. 27, accessed September 25, 2014, at https://store.coloradogeologicalsurvey.org/.

Birkeland, P.W., Shroba, R.R., Burns, S.F., Price, A.B., and Tonkin, P.J., 2003, Integrating soils and geomorphology in mountains-An example from the Front Range of Colorado: Geomorphology, v. 55, no. 1-4, p. 329-344. [Also available at https://doi.org/10.1016/S0169-555X(03)00148-X.]

Bjorklund, L.J., and Brown, R.F., 1957, Geology and groundwater resources of the lower South Platte River Valley between Hardin Colorado, and Paxton Nebraska: U.S. Geological Survey Water-Supply Paper 1378, 431 p. [Also available at https://doi.org/10.3133/wsp1378.]

Braddock, W.A., and Cole, J.C., 1978, Preliminary geologic map of the Greeley $1^{\circ} \times 2^{\circ}$ quadrangle, Colorado and Wyoming: U.S. Geological Survey Open-File Report OF 78-532, 11 p., 1 sheet, scale 1:250,000. [Also available at https://doi.org/10.3133/ofr78532.]

Brush Tribune, 1901, Big flood on Wild Cat: Brush, Colo., Brush Tribune, v.5, no. 34, June 14, 1901, accessed August 2018, at https://www.coloradohistoricnewspapers. org/?a=d\&d=BRT19010614-01.2.3\&e=-------en-20--1--txttxIN-------0. [https://www.coloradohistoricnewspapers.org/.]

Brush Tribune, 1902a, Wild Cat Flood: Brush, Colo., Brush Tribune, v. 6, no. 30, May 23, 1902, accessed August 2018, at https://www.coloradohistoricnewspapers. org/?a=d\&d=BRT19020523-01.2.42\&e=-------en-20--1--txttxIN--------0-. [https://www.coloradohistoricnewspapers.org/.]

Brush Tribune, 1902b, Damage on the Wild Cat: Brush, Colo., Brush Tribune, v. 6, no. 41, August 8, 1902, accessed August 2018, at https://www.coloradohistoricnewspapers. org $/ ? \mathrm{a}=\mathrm{d} \& \mathrm{~d}=\mathrm{BRT} 19020808-01.2 .6 \& \mathrm{e}=08-08-1902-----e n-$ 20-BNT-1--txt-txIN--------0-. [https://www.coloradohistoricnewspapers.org/.]

Bryan, K., and Ray, L.L., 1940, Geologic antiquity of the Lindenmeier site in Colorado: Washington, D.C., Smithsonian Miscellaneous Collections, v. 99, no. 2, 76 p. [Also available at https://repository.si.edu/bitstream/ handle/10088/23695/SMC_99_Bryan_1940_2_1-76.pdf.]

Bryant, B., McGrew, L.W., and Wobus, R.A., 1981, Geologic map of the Denver 1 degree $\times 2$ degrees quadrangle, northcentral Colorado: U.S. Geological Survey Miscellaneous Investigations Series Map I-1163, 1:250,000. [Also available at https://doi.org/10.3133/i1163.]

Bull, W.B., 1990, Stream-terrace genesis-Implications for soil development, in Knuepfer, P.L.K., and McFadden,
L.D., eds., Soils and landscape evolution, 1990

Binghamton Geomorphology Symposium: Geomorphology, v. 3, p. 351-367. [Also available at https://doi.org/10.1016/0169-555X(90)90011-E.]

Carlson, A.E., 2013, Paleoclimate-The Younger Dryas climate event, in Elias, S.A., ed., Encyclopedia of Quaternary Science (2d): Amsterdam, Elsevier Science Publishers B.V. (North-Holland), p. 126-134.

Chapman, S.S., Griffith, G.E., Omernik, J.M., Price, A.B., Freeouf, J.A., and Schrupp, D.L., 2006, Ecoregions of Colorado: U.S. Geological Survey, scale 1,200,000, accessed April 21, 2010, at https://www.epa.gov/eco-research/ ecoregion-download-files-state-region-8. [color poster with map, descriptive text, summary tables, and photographs.]

Church, M., and Ryder, J.M., 1972, Paraglacial sedimentationA consideration of fluvial processes conditioned by glaciation: Geological Society of America Bulletin, v. 83, p. 3059-3072. [Also available at https://doi.org/10.113 0/0016-7606(1972)83[3059:PSACOF]2.0.CO;2.]

Clarke, M.L., and Rendell, H.M., 2003, Late Holocene dune accretion and episodes of persistent drought in the Great Plains of northeastern Colorado: Quaternary Science Reviews, v. 22, no. 10-13, p. 1051-1058. [Also available at https://doi.org/10.1016/S0277-3791(03)00024-6.]

Cohen, K.M., Finney, S.C., Gibbard, P.L. and Fan, J.X., 2013; updated, The ICS International Chronostratigraphic Chart: Episodes, v. 36, no. 3, p. 199-204, accessed February 6, 2017, at http://www.stratigraphy.org/ICSchart/ ChronostratChart2016-12.pdf.

Colorado Division of Water Resources, 2013, Well permit information: Colorado Division of Water Resources Laserfiche WebLink, well locations and subsurface lithologic data accessed December 2013, at http://dwrweblink.state.co.us/ dwrweblink/.

Colton, R.B., 1978, Geologic map of the Boulder-Fort Collins-Greeley area, Front Range urban corridor, Colorado: U.S. Geological Survey Miscellaneous Investigations Map I-855-G, scale 1:100,000. [Also available at https://doi.org/10.3133/i855G.]

Cooke, R.U., and Reeves, R.W., 1976, Arroyos and environmental change in the American South-West: Clarendon Press-Oxford University Press, 213 p.

Dethier, D.P., Schildgen, T., Bierman, P., and Caffee, M., 2001, Cosmogenic analysis of the Rocky Flats Alluvium near Boulder, Colorado [abs.], in Quaternary Geology/ Geomorphology [posters], GSA Annual Meeting, November 5-8, 2001, Boston, Mass.: Geological Society of America Abstracts with Programs, v. 33, no. 6, p. A312-A313. [Also available at https:/gsa.confex.com/gsa/2001AM/ finalprogram/abstract_27712.htm.] 
Dille, J.M., 1960, Irrigation in Morgan County: Fort Morgan, Colo., Farmers State Bank, 58 p. [Holdings of The State Historical Society of Colorado, available at Hart Research Library-History Colorado.]

Dühnforth, M., Anderson, R.S., Ward, D.J., and Blum, A., 2012, Unsteady late Pleistocene incision of streams bounding the Colorado Front Range from measurements of meteoric and in situ ${ }^{10} \mathrm{Be}$ : Journal of Geophysical Research, v. 117, F01023, 20 p., accessed on February 2013, at https:// doi.org/10.1029/2011JF002232.

Eschner, T.R., Hadley, R.F., and Crowley, K.D., 1983, Hydrologic and morphologic changes in channels of the Platte River basin in Colorado, Wyoming, and Nebraska-A historical perspective, chap. A of Eschner, T.R., Hadley, R.F., and Crowley, K.D, eds., Hydrologic and geomorphic studies of the Platte River Basin: U.S. Geological Survey Professional Paper 1277-A, p. A1-A39. [Also available at https://doi.org/10.3133/pp1277.]

Forman, S.L., Oglesby, R., Markgraf, V., and Stafford, T., 1995, Paleoclimatic significance of late Quaternary eolian deposition on the Piedmont and High Plains, central United States: Global and Planetary Change, v. 11, p. 35-55. [Also available at https://doi.org/10.1016/0921-8181(94)00015-6.]

Foster, M.A., Anderson, R.S., Gray, H.J., and Mahan, S.A., 2015, Absolute dating of strath terraces along the western High Plains reveals complicated history of occupation and incision [abs. no. EP53A-0951], in Earth and Planetary Surface Processes, San Francisco, Calif., December 14-18, 2015 Fall Meeting: San Francisco, Calif., American Geophysical Union [Also available at http://abstractsearch. agu.org/meetings/2015/FM/EP53A-0951.html.]

Foster, M.A., Anderson, R.S., Rindfleisch, P.R., Birkeland, P.W., Redwine, J.R., Pitlick, J., and Glade, R.C., 2016, The 2016 Kirk Bryan field trip-Quaternary landslides, fluvial terraces, and recent geomorphic events along the Colorado Front Range, in Keller, S.M., and Morgan, M.L., eds., Unfolding the geology of the West: Geological Society of America Field Guide 44, p. 267-289, accessed February 2017, at http://rock.geosociety.org/Store/ detail.aspx?id=FLD044.

Gardner, M.E., 1967, Quaternary and engineering geology of the Orchard, Weldona, and Fort Morgan quadrangles, Morgan County, Colorado: Golden, Colorado School of Mines, Ph.D. dissertation, 283 p., 3 sheets, scale 1:24,000.

Gilbert, G.K., 1897, Pueblo folio, Colorado, Folios of the Geologic Atlas 36: U.S. Geological Survey Atlas, Folio 36, 7 p., 6 pl. [Also available at https://doi.org/10.3133/gf36.]

Harvey, M.D., Crews, S., Pitlick, J., and Blair, T.C., 1985, Field Trip 5-Holocene braided streams of eastern Colorado and sedimentological effects of Lawn Lake Dam failure, Rocky Mountain National Park, in Flores, R.M., and Harvey, M.D., eds., Field guidebook to modern and ancient fluvial systems in the United States, Fort Collins, Colo., August 7-9, 1985, Proceedings: Third International Fluvial Sedimentology Conference, p. 87-105. [Also available at http://archives.datapages.com/data/rocky_sepm/ data/022/022001/pdfs/i.pdf.]

Haynes, C.V., Jr., McFaul, M., Brunswig, R.H., and Hopkins, K.D., 1998, Kersey-Kuner terrace investigations at the Dent and Bernhardt sites, Colorado: Geoarchaeology, v. 13, no.2, p. 201-218. [Also available at https://doi. org/10.1002/(SICI)1520-6548(199802)13:2<201::AIDGEA5>3.0.CO;2-8.]

Holliday, V.T., 1987, Geoarchaeology and late Quaternary geomorphology of the middle South Platte River, northeastern Colorado: Geoarchaeology, v. 2, no. 4, p. 317-329. [Also available at https://doi.org/10.1002/gea.3340020404.]

Hunt, C.B., 1954, Pleistocene and Recent deposits in the Denver area Colorado: U.S. Geological Survey Bulletin 996-C, p. 91-140. [Also available at https://doi.org/10.3133/b996C.]

Izett, G.A., and Wilcox, R.E., 1982, Map showing localities and inferred distribution of the Huckleberry Ridge, Mesa Falls, and Lava Creek ash beds (Pearlette family ash beds) of Pliocene and Pleistocene age in the western United States and southern Canada: U.S. Geological Survey Miscellaneous Investigations Map I-1325, scale 1:4,000,000. [Also available at https://doi.org/10.3133/i1325.]

Kellogg, K.S., Shroba, R.R., Bryant, Bruce, and Premo, W.R., 2008, Geologic map of the Denver West $30^{\prime} \times 60^{\prime}$ quadrangle, north-central Colorado: U.S. Geological Survey Scientific Investigations Map SIM-3000, scale 1:100,000, 48 p. pamphlet. [Also available at https://doi.org/10.3133/sim3000.]

Licciardi, J.M., Clark, P.U., Brook, E.J., Elmore, D., and Sharma, P., 2004, Variable responses of western U.S. glaciers during the last deglaciation: Geology, v. 32, no. 1, p. 81-84. [Also available at https://doi.org/10.1130/G19868.1.]

Licciardi, J.M., and Pierce, K.L., 2008, Cosmogenic exposureage chronologies of Pinedale and Bull Lake glaciations in greater Yellowstone and the Teton Range, USA: Quaternary Science Reviews, v. 27, no. 7-8, p. 814-831. [Also available at https://doi.org/10.1016/j.quascirev.2007.12.005.]

Lindsey, D.A., Langer, W.H., and Knepper, D.H., Jr., 2005, Stratigraphy, lithology, and sedimentary features of Quaternary alluvial deposits of the South Platte River and some of its tributaries east of the Front Range, Colorado: U.S. Geological Survey Professional Paper 1705, 70 p. [Also available at https://doi.org/10.3133/pp1705.]

Madole, R.F., 1986, Lake Devlin and Pinedale glacial history, Front Range, Colorado: Quaternary Research, v. 25, no. 01, p. 43-54. [Also available at https://doi.org/10.1016/00335894(86)90042-6.] 
Madole, R.F., 1991, Colorado Piedmont section, in Wayne, W.J., ed., Quaternary geology of the Northern Great Plains, chap. 15 of Morrison, R.B., ed., Quaternary nonglacial geology_Conterminous U.S.: Boulder, Colo., Geological Society of America, The Geology of North America, v. K2, p. 456-462. [Also available at http://rock.geosociety.org/ Store/detail.aspx?id=DNAGGNAK2.]

Madole, R.F., 1994, Stratigraphic evidence of desertification in the west-central Great Plains within the past $1000 \mathrm{yr}$ : Geology, v. 22, p. 483-486. [Also available at https://doi. org/10.1130/0091-7613(1994)022<0483:SEODIT>2.3.CO;2.]

Madole, R.F., 1995, Spatial and temporal patterns of late Quaternary eolian deposition, eastern Colorado, U.S.A.: Quaternary Science Reviews, v. 14, no. 2, p. 155-177. [Also available at https://doi.org/10.1016/0277-3791(95)00005-A.]

Madole, R.F., Honke, J.S., and Langdon, P.G., 2010, Evidence from the Front Range, Colorado, indicates that Pinedale glaciation began before $31,000 \mathrm{yr}$ ago [abs.], in Timing of Pleistocene glaciation in the North American Cordillera, 2010 GSA Annual Meeting, October 31-November 3, 2010: Geological Society of America Abstracts with Programs, v. 42 , no. 5 , p. 363. [Also available at https://gsa.confex. com/gsa/2010AM/finalprogram/abstract_177100.htm.]

Madole, R.F., VanSistine, D.P., and Michael, J.A., 1998, Pleistocene glaciations in the upper Platte River drainage basin, Colorado: U.S. Geological Survey Geologic Investigations Series I-2644. [Also available at https://doi.org/10.3133/i2644.]

Madole, R.F., VanSistine, D.P., and Michael, J.A., 2005, Distribution of late Quaternary wind-deposited sand in eastern Colorado: U.S. Geological Survey Scientific Investigations Map 2875, scale 1:700,000, 49 p. pamphlet. [Also available at https://doi.org/10.3133/sim2875.]

Mahan, S.A., Noe, D.C., and McCalpin, J.P., 2009, Use of OSL dating to establish the stratigraphic framework of Quaternary eolian sediments, Anton scarp upper trench, northeastern Colorado High Plains, USA: Quaternary International, v. 199, p. 92-103. [Also available at https:// doi.org/10.1016/j.quaint.2008.09.006.]

Matthews, N.E., Vázquez, J.A.; Calvert, A.T., 2015, Age of the Lava Creek supereruption and magma chamber assembly at Yellowstone based on ${ }^{40} \mathrm{Ar} /{ }^{39} \mathrm{Ar}$ and U-Pb dating of sanidine and zircon crystals: Geochemistry, Geophysics, Geosystems, v. 16, p. 2508-2528, accessed September 2018, at https://doi.org/10.1002/2015GC005881.

McFaul, M., Traugh, K.L., Smith, G.D., Doering, W., and Zier, C.J., 1994, Geoarchaeologic analysis of South Platte River terraces-Kersey, Colorado: Geoarchaeology, v. 9, no. 5, p. 345-374. [Also available at https://doi.org/10.1002/ gea.3340090502.]
Meko, D.M., 1992, Dendroclimatic evidence from the Great Plains of the United States in Bradley, R.S., and Jones, P.D., eds., Climate Since A.D. 1500: London, United Kingdom, Routledge, p. 312-330.

Menounos, B., and Reasoner, M.A., 1997, Evidence for cirque glaciation in the Colorado Front Range during the Younger Dryas chronozone: Quaternary Research, v. 48, p. 38-47. [Also available at https://doi.org/10.1006/qres.1997.1902.]

Muhs, D.R., 1985, Age and paleoclimatic significance of Holocene sand dunes in northeastern Colorado: Annals of the Association of American Geographers, v. 75 , no. 4 , p. 566-582. [Also available at https:// doi.org/10.1111/j.1467-8306.1985.tb00094.x.]

Muhs, D.R., 2017, Evaluation of simple geochemical indicators of aeolian sand provenance - Late Quaternary dune fields of North America revisited: Quaternary Science Reviews, v. 171, p. 260-296, accessed August 2017, at https://doi.org/10.1016/j.quascirev.2017.07.007.

Muhs, D.R., and Holliday, V.T., 1995, Evidence of active dune sand on the Great Plains in the 19th century from accounts of early explorers: Quaternary Research, v. 43, p. 198-208. [Also available at https://doi.org/10.1006/qres.1995.1020.]

Muhs, D.R., Stafford, T.W., Cowherd, S.D., Mahan, S.A., Kihl, R., Maat, P.B., Bush, C.A., and Nehring, J., 1996, Origin of the late Quaternary dune fields of northeastern Colorado: Geomorphology, v. 17, no. 1-3, p. 129-149. [Also available at https://doi.org/10.1016/0169-555X(95)00100-J.]

Muhs, D.R., Aleinikoff, J.N., Stafford, T.W., Jr., Kihl, R., Been, J., Mahan, S.A., and Cowherd, S.D., 1999a, Late Quaternary loess in northeastern Colorado — Part I—Age and paleoclimatic significance: Geological Society of America Bulletin, v. 111, no. 12, p. 1861-1875. [Also available at https://doi. org/10.1130/0016-7606(1999)111<1861:LQLINC>2.3.CO;2.]

Muhs, D.R., Swinehart, J.B., Loope, D.B., Aleinikoff, J.N., and Been, Josh, 1999b, 200,000 years of climate change recorded in eolian sediments of the High Plains of eastern Colorado and western Nebraska, in Lageson, D.R., Lester, A.P., and Trudgill, B.D., eds., Colorado and Adjacent Areas: Boulder, Colo., Geological Society of America Field Guide 1, p. 71-91. [Also available at http://rock.geosociety.org/ Store/detail.aspx?id=FLD001.]

Nadler, C.T., and Schumm, S.A., 1981, Metamorphosis of South Platte and Arkansas Rivers, eastern Colorado: Physical Geography, v. 2, no. 2, p. 95-115. [Also available at https://doi.org/10.1080/02723646.1981.10642207.]

Nelson, A.R., Millington, A.C., Andrews, J.T., and Nichols, H., 1979, Radiocarbon-dated upper Pleistocene glacial sequence, Fraser Valley, Colorado Front Range: Geology, v. 7, no. 8, p. 410-414. [Also available at https://doi. org/10.1130/0091-7613(1979)7<410:RUPGSF>2.0.CO;2.] 
Paces, J.B., 2015, ${ }^{230} \mathrm{Th} / \mathrm{U}$ ages supporting geologic map of the Masters 7.5' quadrangle, Weld and Morgan Counties, Colorado [appendix], in Berry, M.E., Slate, J.L., Paces, J.B., Hanson, P.R., and Brandt, T.R., Geologic map of the Masters 7.5' quadrangle, Weld and Morgan Counties, Colorado: U.S. Geological Survey Scientific Investigations Map 3344, 10 p. appendix, 1:24,000, accessed September 2015, at https://doi.org/10.3133/sim3344.

Pierce, K.L., 2003, Pleistocene glaciations of the Rocky Mountains, in Gillespie, A.R., Porter, S.C., and Atwater, B.F., eds., Developments in Quaternary Sciences, The Quaternary Period in the United States, Volume 1: Amsterdam, Elsevier, p. $63-76$.

Pigati, J.S., McGeehin, J.P., Muhs, D.R., and Bettis, E.A., III, 2013, Radiocarbon dating late Quaternary loess deposits using small terrestrial gastropod shells: Quaternary Science Reviews, v. 76, p. 114-128. [Also available at https://doi. org/10.1016/j.quascirev.2013.05.013.]

Pigati, J.S., Rech, J.A., and Nekola, J.C., 2010, Radiocarbon dating of small terrestrial gastropod shells in North America: Quaternary Geochronology, v. 5, p. 519-532. [Also available at https://www.sciencedirect.com/science/ article/pii/S1871101410000026?via\%3Dihub.]

Rasmussen S.O., Andersen, K.K., Svensson, A.M., Steffensen, J.P., Vinther, B.M., Clausen, H.B. Siggaard-Andersen, M.-L., Johnsen, S.J., Larsen, L.B., Dahl-Jensen, D., Bigler, M., Röthlisberger, R., Fischer, H., Goto-Azuma, K., Hansson, M.E., and Ruth, U., 2006, A new Greenland ice core chronology for the last glacial termination: Journal of Geophysical Research, v. 111, 16 p., accessed August 2018, at http://doi.org/10.1029/2005JD006079.

Reimer, P.J., Bard, E., Bayliss, A., Beck, J.W., Blackwell, P.G., Ramsey, C.B., Buck, C.E., Cheng, H., Edwards, R.L., Friedrich, M., Grootes, P.M., Guilderson, T.P., Haflidason, H., Hajdas, I., Hatté, C., Heaton, T.J., Hoffmann, D.L., Hogg, A.G., Hughen, K.A., Kaiser, K.F., Kromer, B., Manning, S.W., Niu, M., Reimer, R.W., Richards, D.A., Scott, E.M., Southon, J.R., Staff, R.A., Turney, C.S.M., and van der Plicht, J., 2013, IntCal13 and Marine13 radiocarbon age calibration curves, 0-50,000 years cal B.P.: Radiocarbon, v. 55, no. 4, p. 1869-1887., accessed March 2014, at https://doi.org/10.2458/azu_js_rc.55.16947.

Rengers, F.K., and Tucker, G.E., 2014, Analysis and modeling of gully headcut dynamics, North American High Plains: Journal of Geophysical Research Earth Surface, v. 119, p. 983-1003, accessed May 2016, at https:// doi.org/10.1002/2013JF002962.

Rengers, F.K., and Tucker, G.E., 2015, The evolution of gully headcut morphology-A case study using terrestrial laser scanning and hydrological monitoring: Earth Surface Processes and Landforms, v. 40, p. 1304-1317, accessed October 2016, at https://doi.org/10.1002/esp.3721.
Rengers, F.K., Tucker, G.E., and Mahan, S.A., 2016, Episodic bedrock erosion by gully-head migration, Colorado High Plains, USA: Earth Surface Processes and Landforms, v. 41, 1574-1582., accessed October 2016, at https://doi. org/10.1002/esp.3929.

Riihimaki, C.A., Anderson, R.S., Safran, E.B., Dethier, D.P., Finkel, R.C., and Bierman, P.R., 2006, Longevity and progressive abandonment of the Rocky Flats surface, Front Range, Colorado: Geomorphology, v. 78, p. 265-278. [Also available at https://doi.org/10.1016/j.geomorph.2006.01.035.]

Ritter, D.F., 1987, Fluvial processes in the mountains and intermontane basins, in Madole, R.F., and others, Rocky Mountains, chap. 7 of Graf, W.L., ed., Geomorphic systems of North America: Geological Society of America, Centennial Special Volume 2, p. 220-228.

Roy, M., Clark, P.U., Barendregt, R.W., Glasmann, J.R., Enkin, R.J., 2004, Glacial stratigraphy and paleomagnetism of late Cenozoic deposits of the north-central United States: Geological Society of America Bulletin, v. 116, no. 1-2, p. 30-41. [Also available at https://doi.org/10.1130/B25325.1.]

Schaefer, J.M., Denton, G.H., Barrell, D.J.A., Ivy-Ochs, S., Kubik, P.W., Andersen, B.G., Phillips, F.M., Lowell, T.V., and Schlüchter, C., 2006, Near-synchronous interhemispheric termination of the last glacial maximum in midlatitudes: Science, v. 312, p. 1510-1513, accessed February 2014, at https://doi.org/10.1126/science.1122872.

Schildgen, T., Dethier, D.P., Bierman, P., and Caffee, M., $2002,{ }^{26} \mathrm{Al}$ and ${ }^{10} \mathrm{Be}$ dating of late Pleistocene and Holocene fill terraces - A record of fluvial deposition and incision, Colorado Front Range: Earth Surface Processes and Landforms, v. 27, no. 7, p. 773-787. [Also available at https:// doi.org/10.1002/esp.352.]

Schumm, S.A., 1973, Geomorphic thresholds and complex response of drainage systems, in Morisawa, M., ed., Fluvial Geomorphology, Proceedings of the Fourth Annual Geomorphology Symposia Series held at Binghamton, N.Y., Sept. 27-28, 1973: Allan and Unwin, The University of Michigan, p. 299-310.

Schweinsberg, A.D., Briner, J.P., Shroba, R.R., Licciardi, J.M., Leonard, E.M., Brugger, K.A., and Russell, C.M., 2016, Pinedale glacial history of the upper Arkansas River valley-New moraine chronologies, modeling results, and geologic mapping, in Keller, S.M., and Morgan, M.L., eds., Unfolding the geology of the West: Geological Society of America Field Guide 44, p. 335-353, accessed June 2017, at http://rock.geosociety.org/Store/detail.aspx?id=FLD044.

Scott, G.R., 1960, Subdivision of the Quaternary alluvium east of the Front Range near Denver, Colorado: Geological Society of America Bulletin, v. 71, no. 10, p. 1541-1543. [Also available at https://doi.org/10.1130/00167606(1960)10[1541:SOTQAE]2.0.CO;2.] 
Scott, G.R., 1963, Quaternary geology and geomorphic history of the Kassler quadrangle, Colorado, chap. A of Geology of the Kassler quadrangle, Jefferson and Douglas Counties, Colorado: U.S. Geological Survey Professional Paper 421, 70 p. [Also available at https://doi.org/10.3133/pp421A.]

Scott, G.R., 1972, Geologic map of the Morrison quadrangle, Jefferson County, Colorado: U.S. Geological Survey Quadrangle Map I-790-A, scale 1:24,000. [Also available at https://doi.org/10.3133/i790A.]

Scott, G.R., 1975, Cenozoic surfaces and deposits in the southern Rocky Mountains, in Curtis, B.F., ed., Cenozoic history of the southern Rocky Mountains: Geological Society of America Memoir 144, p. 227-248. [Also available at http:// rock.geosociety.org/Store/detail.aspx?id=MWR144.]

Scott, G.R., 1978, Map showing geology, structure, and oil and gas fields in the Sterling $1^{\circ} \times 2^{\circ}$ quadrangle, Colorado, Nebraska, and Kansas: U.S. Geological Survey Miscellaneous Investigations Series Map I-1092, 1:250,000. [Also available at https://doi.org/10.3133/i1092.]

Scott, G.R., 1982, Paleovalley and geologic map of northeastern Colorado: U.S. Geological Survey Miscellaneous Investigations Series Map I-1378, 1:250,000. [Also available at https://doi.org/10.3133/i1378.]

Sharp, W.D., Ludwig, K.R., Chadwick, O.A., Amundson, R., and Glaser, L.L., 2003, Dating fluvial terraces by ${ }^{230} \mathrm{Th} / \mathrm{U}$ on pedogenic carbonate, Wind River Basin, Wyoming: Quaternary Research, v. 59, no. 02, p. 139-150. [Also available at https://doi.org/10.1016/S0033-5894(03)00003-6.]

Sharps, J.A., 1980, Geologic map of the Limon $1^{\circ} \times 2^{\circ}$ quadrangle, Colorado and Kansas: U.S. Geological Survey Miscellaneous Investigations Series Map I-1250, 1:250,000. [Also available at https://doi.org/10.3133/i1250.]

Smith, R.O., Schneider, P.A., Jr., and Petri, L.R., 1964, Ground-water resources of the South Platte River basin in western Adams and southwestern Weld Counties, Colorado: U.S. Geological Survey Water-Supply Paper 1658, 132 p. [Also available at https://doi.org/10.3133/wsp1658.]

Stuiver, M., and Reimer, P.J., 1993, Extended ${ }^{14} \mathrm{C}$ database and revised CALIB radiocarbon calibration program: Radiocarbon, v. 35, no. 01, p. 215-230. [Also available at https://doi.org/10.1017/S0033822200013904.]

Swinehart, J.B., Dreeszen, V.H., Richmond, G.M., Tipton, M.J., Bretz, R.F., Steece, F.V., Hallberg, G.R., and Goebel, J.E., state compilers, edited and integrated by Richmond, G.M., 1994, Quaternary geologic map of the Platte River 4 degree $\times 6$ degree quadrangle, United States: U.S. Geological Survey Miscellaneous Investigations Series Map I-1420 (NK-14), scale 1:1,000,000. [Also available at https://doi.org/10.3133/i1420(NK14).]
Szabo, B.J., 1980, Results and assessment of uranium-series dating of vertebrate fossils from Quaternary alluviums in Colorado: Arctic and Alpine Research, v. 12, no. 1, p. 95-100. [Also available at https://www.tandfonline.com/ doi/abs/10.1080/00040851.1980.12004166.]

U.S. Department of Agriculture (USDA) Natural Resources Conservation Service, 2009a, Soil survey geographic (SSURGO) database for Morgan County, Colo.: U.S. Department of Agriculture Natural Resources Conservation Service, co087, accessed January 27, 2011, at https:// websoilsurvey.nrcs.usda.gov/.

U.S. Department of Agriculture (USDA) Natural Resources Conservation Service, 2009b, Soil survey geographic (SSURGO) database for Weld County, Colorado, southern part: U.S. Department of Agriculture Natural Resources Conservation Service, co618, accessed January 27, 2011, at https://websoilsurvey.nrcs.usda.gov/.

Walker, J.D., Geissman, J.W., Bowring, S.A., and Babcock, L.E., compilers, 2012a, Geologic time scale v. 4.0: Boulder, Colo., Geological Society of America, accessed January 2015, at https://www.geosociety.org/documents/gsa/ timescale/timescl-2012.pdf.

Walker, M.J.C., Berkelhammer, M., Björck, S., Cwynar, L.C., Fisher, D.A., Long, A.J., Lowe, J.J., Newnham, R.M., Rasmussen, S.O., and Weiss, H., 2012b, Formal subdivision of the Holocene Series/Epoch-A discussion paper by a working group of INTIMATE (Integration of ice-core, marine and terrestrial records) and the Subcommission on Quaternary Stratigraphy (International Commission on Stratigraphy): Journal of Quaternary Science, v. 27 , no. 7, p. 649-659, accessed September 2013, at https://doi.org/10.1002/jqs.2565.

Williams, G.P., 1978, The case of the shrinking channels; the North Platte and Platte Rivers in Nebraska: U.S. Geological Survey Circular 781, 48 p. [Also available at https:// doi.org/10.3133/cir781.]

Woodhouse, C.A., and Brown, P. M., 2001, Tree-ring evidence for Great Plains drought: Tree-Ring Research, v. 57, no. 1, p. 89-103. [Available from the University of Arizona Library Repository.]

Woodhouse, C.A., Lukas, J.J., and Brown, P.M., 2002, Drought in the western Great Plains, 1845-56, Impacts and implications: Bulletin of the American Meteorological Society, v. 83, p. 1485-1493. [Also available at https:// doi.org/10.1175/BAMS-83-10-1485.]

Young, N.E., Briner, J.P., Leonard, E.M., Licciardi, J.M., and Lee, K., 2011, Assessing climatic and nonclimatic forcing of Pinedale glaciation and deglaciation in the western United States: Geology, v. 39, no. 2, p. 171-174. [Also available at https://doi.org/10.1130/G31527.1.] 
Publishing support provided by the Science Publishing Nework, Denver Publishing Service Center

For more information concerning the research in this report, contact the Center Director,

USGS Geosciences and Environmental Change Science Center Box 25046, Mail Stop 980

Denver, CO 80225

(303) 236-5344

Or visit the Geosciences and Environmental Change Science Center website at https://www.usgs.gov/centers/gecsc 


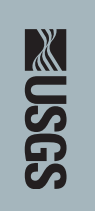

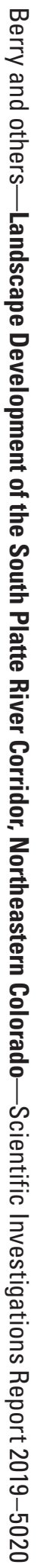

